Mohd Aizam \& Mohd Fauzi, "Pemikiran Skeptikal Syiah terhadap Ahl alSunnah wa al-Jamā'ah," Afkār Vol. 21 Issue 1 (2019): 1-52

\title{
PEMIKIRAN SKEPTIKAL SYIAH TERHADAP AHL AL-SUNNAH WA AL-JAMĀ'AH DALAM KARYA-KARYA SYIAH MELAYU: SATU KRITIKAN
}

SHI'ITE'S SCEPTICAL VIEW TOWARDS AHL ALSUNNAH WA AL-JAMĀ'AH IN MALAY SHI'ITE WORKS: A CRITIC

\section{Mohd Aizam Mas'od* \& Mohd Fauzi Hamat**}

*Buhuth Unit. Mufti of Federal Territory Office. Prime Minister's Department. Kompleks Islam Putrajaya. 62100. Putrajaya. Malaysia.

**Department of `Aqidah \& Islamic Thought. Academy of Islamic Studies. University of Malaya. 50603. Kuala Lumpur. Malaysia.

Email: *abuhaseef@live.com

DOI: https://doi.org/10.22452/afkar.vol21no1.1

\section{Khulasah}

Fahaman Syiah telah tersebar di Malaysia menjelang tahun 1980-an selepas berlaku Revolusi Iran pada tahun 1979. Dalam konteks Malaysia, proses penyebaran Syiah kepada masyarakat Melayu berlaku menerusi pelbagai cara. Antara medium penyebaran yang memberikan impak ketara adalah penyebaran karya-karya Syiah berbahasa Melayu. Terdapat pelbagai dakwaan dilemparkan terhadap Ahl alSunnah wa al-Jamā'ah dalam karya-karya Syiah Melayu bagi meragukan keabsahannya sebagai sebuah mazhab. Antaranya mempertikaikan hujah Ahl alSunnah sebagai golongan majoriti sedangkan majoriti tidak semestinya benar. Mendakwa kewujudan Ahl alSunnah wa al-Jamā'ah tidak memiliki sandaran yang kukuh dari segi syarak dan sejarah. Meragui keperibadian al-Ash'ari kerana berasal dari seorang tokoh $\mathrm{Mu}$ 'tazilah dan menuduh Ahl al-Sunnah wa alJamā'ah sebagai sebuah pakatan yang rapuh kerana menyaksikan pelbagai pertembungan dari sudut 
akidah dan fiqah. Justeru, artikel ini membentangkan kritikan ilmiah terhadap hujah-hujah yang dikemukakan Syiah dalam karya-karya berkenaan. Menerusi metod dokumentasi dalam kaedah pengumpulan data, kajian ini merujuk kepada dua buah karya Syiah Melayu terpilih iaitu Meniti Titian Kebenaran karangan Khair Izzah dan Perempuan Nan Bercinta karya Faisal Tehrani. Manakala metode komperatif digunakan dalam menganalisis data dengan membuat perbandingan hujah antara Syiah dan Ahl al-Sunnah wa al-Jamā'ah. Secara umumnya, semua keraguan yang dibangkitkan dalam beberapa karya Syiah Melayu adalah bagi menjustifikasikan kebatilan mazhab Ahl al-Sunnah wa al-Jamā'ah, sekaligus menetapkan Syiah sebagai satu-satunya mazhab yang sah. Walau bagaimanapun, hujah-hujah yang dipaparkan dalam karya-karya tersebut adalah tertolak kerana sarat dengan penyelewengan fakta dan pengkhianatan ilmiah.

Kata kunci: Pemikiran skeptikal; karya-karya Syiah Melayu; Shī'ah Imāmiyyah Ithnā 'Ashariyyah; Ahl alSunnah wa al-Jamā'ah; Malaysia.

\begin{abstract}
Shi'a has been spread in Malaysia by the 1980s after the Iranian revolution in 1979. In the Malaysian context, dissemination of Shi ite to the Malay community occurred through a variety of ways. Among the spreading mediums that had a primary impact were the spread of Malay Shi'ite works. Various allegations were made about Ahl al-Sunnah wa al-Jamā'ah in Malay Shi'ite works to cast doubt on its legitimacy as a school of thought by questioning the argument of Ahl al-Sunnah as being the majority while the majority is not necessarily right. Shi 'ite also claims that the existence of Ahl al-Sunnah wa al-Jamā'ah has no strong religious and historical basis. Besides, the school raise doubt on the personality of al-Ash'ari as a former Mu'tazilah figure and accuse Ahl al-Sunnah wa al-Jamā'ah as having formed a weak alliance
\end{abstract}


Mohd Aizam \& Mohd Fauzi, "Pemikiran Skeptikal Syiah terhadap Ahl alSunnah wa al-Jamā'ah," Afkār Vol. 21 Issue 1 (2019): 1-52

between its components from within the school because of different views among themselves in some issues of 'aqidah and jurisprudence (fiqh). Hence, this article presents critics on the arguments suggested by Shi'ite in the works. Through the method of documentation in the method of data collection, this study refers to two selected Malay Shi'ite works entitled Meniti Titian Kebenaran by Khair Izzah and Perempuan Nan Bercinta by Faisal Tehrani. Whereas comparative methods are used in analyzing data by comparing the arguments between Shi'ite and Ahl alSunnah wa al-Jamā'ah. In general, all these doubts were raised in some of the Malay Shi'ite works to justify the falsehood of Ahl al-Sunnah wa alJamā'ah's practice, at the same time establishing Shi'ite as the only legitimate school of thought. However, the arguments presented in the works were rejected because of the manipulation of facts and scientific treachery.

Keywords: Sceptical view; Malay Shi'ite works; Shỉ'ah Imāmiyyah Ithnā 'Ashariyyah; Ahl al-Sunnah wa al-Jamā'ah; Malaysia.

\section{Pendahuluan}

Syiah Imāmiyyah Ithnā 'Ashariyyah merupakan aliran yang secara konsisten menolak prinsip keadilan para sahabat. Menurut aliran ini, hukum mengenai keadilan para sahabat adalah sepertimana hukum ke atas selain mereka. Gelaran sahabat semata-mata tidak boleh menjadikan mereka adil secara langsung dan kebal daripada sebarang penilaian dan kritikan. Syiah meletakkan tiga kayu ukur utama bagi menilai keadilan para sahabat iaitu; kecintaan dan permusuhan mereka terhadap Ahl al-Bayt, kemungkaran yang dilakukan mereka ketika hayat Rasulullah SAW dan kemurtadan mereka selepas kewafatan Rasulullah SAW.

Penolakan terhadap keadilan para sahabat menjustifikasikan Syiah untuk menolak para sahabat sebagai sumber rujukan atau sandaran dalam beragama. Ia 
berasaskan kedudukan para sahabat yang didakwa tidak boleh dipercayai, memiliki banyak kekurangan dan keburukan, terdedah kepada perlakuan munafik, fasik dan murtad yang boleh dipertikaikan kredibilitinya. Lebih-lebih lagi jika dibandingkan dengan para imam Ahl al-Bayt yang bersifat maksum menurut iktikad Syiah. Hal ini menjadikan Syiah bersikap amat skeptikal terhadap mazhab Ahl alSunnah wa al-Jamā'ah yang sering dikaitkan secara tipikal dengan mazhab sahabat. Manakala Syiah pula menyandarkan diri mereka sebagai mazhab Ahl al-Bayt.

Makalah ini akan meneliti beberapa pandangan skeptikal tersebut dalam dua karya Syiah Melayu, Meniti Titian Kebenaran: Menyingkap Kebenaran Mazhab Rasul dan Ahlul Bait ${ }^{1}$ karangan Khair Izzah dan Perempuan Nan Bercinta $^{2}$ karangan Faisal Tehrani. Kedua-dua karya berkenaan telah dikenakan perintah larangan oleh Kementerian Dalam Negeri, masing-masing pada 9 Januari 2014, No. Warta P.U. (A) 13 dan 22 April 2014, No. Warta P.U. (A) 111. Antara sebab utama larangan adalah kerana mempromosikan fahaman Syiah yang bertentangan dengan pegangan Ahl al-Sunnah wa al-Jamā'ah yang menjadi anutan rasmi di Malaysia. ${ }^{3}$

\section{Pengenalan Terhadap Dua Karya Syiah Melayu}

\section{a. Khair Izzah dan karyanya Meniti Titian Kebenaran} Khair Izzah merupakan nama samaran kepada Khaireen Syahreen bin A Malek. Beliau menjalankan perniagaan

${ }^{1}$ Khair Izzah, Meniti Titian Kebenaran (t.t.p. : Al-Muntazar Resources, 2011).

2 Faisal Tehrani, Perempuan Nan Bercinta (Kuala Lumpur: ITBM, 2012).

3 "Senarai Perintah Larangan", Kementerian Dalam Negeri, dicapai 15 Mei 2015, http://epq.kdn.gov.my/epq/index.php?mod=public\&opt=pl; Mohd Aizam Mas'od dan Mohd Fauzi Hamat, "Analisis Definisi Sahabat dalam Beberapa Karya Syiah Melayu," Jurnal Akidah \& Pemikiran Islam (Afkar) Vol. 20 Issue 1 (2018), doi: https://doi.org/10.22452/afkar.vol20no1.1, 4. 
mengedar dan menjual buku-buku kajian, komputer, barangan aksesori dan penternakan itik dan kambing di bawah Syarikat Raudhah al-Hurr Resources Enterprise beralamat di Ulu Tiram, Johor. Dalam kata pengantar buku Meniti Titian Kebenaran, beliau mengaku sebagai penuntut di Kuliah Usuluddin dan Dakwah, Universiti al-Azhar, Mesir. Selain mengarang buku Meniti Titian Kebenaran, beliau juga mengarang buku lain yang turut mempertahankan ajaran Syiah Imāmiyyah Ithnā 'Ashariyyah dan mengkritik Ahl al-Sunnah wa al-Jamā'ah iaitu Pertahan Syariat Muhammadiyah pada 2010. Selain itu, beliau pernah mewakili pihak Syiah Imāmiyyah Ithnā 'Ashariyyah dalam Dialog Sunni Syiah yang diadakan di Masjid Jamek Taman Perling, Johor Bahru pada 3 Februari 2013. ${ }^{4}$

Mengenai isi kandungan buku Meniti Titian Kebenaran, secara umumnya ia ditulis dengan jelas bertujuan untuk mempromosikan fahaman Syiah Imāmiyyah Ithnā 'Ashariyyah. Sekalipun tajuk besarnya agak kabur dan bersifat catchy, namun secara penuh disebutkan judulnya, Meniti Titian Kebenaran: Menyingkap Kebenaran Mazhab Rasul dan Ahlul Bait. Tajuk sedemikian sudah cukup menimbulkan tanda tanya di benak pembaca bahawa terdapat suatu mazhab baharu yang selama ini terselindung kebenarannya oleh sebab tertentu. Dalam kata pengantarnya, penulis menekankan kepentingan berfikir dan mengkaji dalam mencari kebenaran. Bukan sekadar bertaqlid kepada ibu bapa atau keturunan yang lebih banyak dipengaruhi oleh sentimen berbanding bersikap rasional dan profesional.

\footnotetext{
${ }^{4}$ Seksyen Akidah, "Kertas Makluman Perkembangan Terkini Isu Syiah di Malaysia" (2013), 10; "Debat Sunni Syiah Masjid Perling 2013: Analisis Ringkas", Meniti Titian Sebenar, http://titiansebenar.blogspot.my/2014/02/debat-sunni-syiah-masjid-perling2013.html, dicapai 10 Januari 2016; "Debat Sunni vs Syiah Malayia, dicapai 10 Januari 2016, https://www.youtube.com/watch?v=NpSUIyUUwZE\&t=42m38s.
} 
Penulis merakamkan kekesalannya yang pernah menilai ajaran Syiah berdasarkan tulisan-tulisan daripada musuh-musuh Syiah. Namun dalam diam-diam beliau cuba mengkaji ajaran Syiah menerusi sumber-sumber Syiah sendiri. Akhirnya ia menjadi titik peralihan dalam pencarian beliau apabila mendapati hujah-hujah yang dikemukakan dalam sumber rujukan Syiah mampu menjawab semua pertikaian yang ditimbulkan oleh para ulama Ahl al-Sunnah wa al-Jamā'ah. Justeru, buku ini ditulis dengan membawakan hujah-hujah al-Qur'an, hadis, sejarah dan logik akal siapakah sebenarnya golongan Syiah Imāmiyyah Ithnā 'Ashariyyah itu. ${ }^{5}$

Seterusnya penulis membahagikan buku ini kepada sembilan topik dengan keseluruhannya 755 halaman, iaitu:

1. Mazhab Majoriti: Mengenali Ahlus Sunnah Wal Jamaah

2. Mazhab Minoriti: Mengenali Syiah Imamiyyah

3. Perbahasan Pertama: Sumber-sumber Asas Aqidah

4. Perbahasan Kedua: Individu Ahlul Bait Nabi SAW

5. Perbahasan Ketiga: Hak Jabatan Khilafah Islam

6. Perbahasan Keempat: Rampasan Hak Jabatan Khilafah

7. Perbahasan Kelima: Keadilan Para Al-sahabah

8. Perbahasan Keenam: Veto Ijtihad vs Nas Syariat

9. Perbahasan Ketujuh: Penciptaan Hadis dan al-Sunnah Nabi

Kesimpulannya, buku ini dikarang oleh penulis sebagai alat propaganda bagi menyebarkan fahaman Syiah Imāmiyyah Ithnā 'Ashariyyah. Argumentasi yang dibentangkan lebih bersifat konfrantatif terhadap fahaman Ahl al-Sunnah wa al-Jamā'ah dan defensif bagi mempertahankan kebenaran ajaran Syiah Imāmiyyah Ithnā 'Ashariyyah.

\footnotetext{
${ }^{5}$ Khair Izzah, Meniti Titian Kebenaran, 1-51 (Kata Pengantar).
} 


\section{b. Faisal Tehrani dan karyanya Perempuan Nan Bercinta}

Faisal Tehrani adalah nama pena bagi Mohd Faizal bin Musa. Beliau merupakan novelis berunsur Islam terkenal di Malaysia. Beberapa buah buku beliau selain buku Perempuan Nan Bercinta telah dikenakan perintah larangan oleh KDN kerana dikenalpasti mengandungi unsur-unsur ajaran Syiah. Antaranya, Sebongkah Batu di Kuala Berang, Karbala dan Ingin Jadi Nasrullah yang dikenakan perintah larangan pada 1 April 2015 dengan Warta No. P.U. (A) $67 .^{6}$

Novel ini dikarang oleh Faisal Tehrani dengan bertemakan novel cinta yang amat digemari oleh golongan remaja tetapi sarat dengan propaganda fahaman Syiah Imāmiyyah Ithnā 'Ashariyyah. Penulis menerapkan elemen perdebatan ilmiah untuk mempengaruhi pembaca bagi menonjolkan keabsahan ajaran Syiah Imāmiyyah Ithnā 'Ashariyyah dari segi epistemologi dan ideologi berbanding mazhab Ahl al-Sunnah wa al-Jamā'ah yang disifatkan sebagai tidak asli. Objektif tersebut tampak menyerlah menerusi kewujudan satu watak protagonis yang mewakili Syiah tetapi mengaku seorang Sunni yang bertasyayyu' Hasan (Dr. Ali Taqi), manakala lima lagi adalah watak antagonis yang mewakili wanita Islam feminis (Idora), penganut Aties (Briana), orientalis Kristian (Bastian), bekas penganut Salafi (Hashemi) dan penganut Sunni (Zanjabila). Menerusi watak Dr. Ali Taqi, penulis menerapkan apa yang menjadi ideologi pegangannya, sesuai dengan penegasannya pada kulit belakang karya tersebut,

"Sejak 1515 dan Tuhan Manusia, Perempuan

Nan Berinta adalah karya Faisal Tehrani yang paling provokatif setakat ini."

6 "Senarai Perintah Larangan", Kementerian Dalam Negeri, http://epq.kdn.gov.my/e-pq/index.php?mod=public\&opt=pl. 15 Mei 2015. 
Secara umumnya, novel ini cuba memberikan gambaran bagaimana pegangan Ahl al-Sunnah wa alJamā'ah yang dianuti oleh majoriti umat Islam di dunia menjadi punca kepada pandangan negatif banyak pihak terhadap imej Islam itu sendiri. Penulis menggunakan instrumen perbualan, pembentangan seminar dan forum bagi mewujudkan perdebatan sama ada secara jelas atau tidak jelas, langsung atau tidak langsung bagi memperlihatkan keabsahan dan kerelevenan ajaran Syiah Imāmiyyah Ithnā 'Ashariyyah dalam menjawab segala persoalan umat bermula daripada isu gender, kekeluargaan, pemikiran pasca modenisme, perbandingan teologi, mazhab dan agama, isu hak asasi dan diskriminasi golongan minoriti, perjuangan Hezbollah dan sejarah awal kedatangan Islam ke Nusantara.

Kesemua topik ini dicerakinkan dengan menjadikan Ahl al-Sunnah wa al-Jamā'ah sebagai sasaran utama terhadap segala kepincangan dalam menangani isu umat. Walau bagaimanapun, penulis menutup novelnya secara anti-klimaks apabila menyatakan Sunni dan Syiah perlu saling melengkapi bagi mencapai matlamat generasi supramazhab, sedangkan idea-idea yang dibentangkan sebelumnya sarat dengan sikap prejudis dan provokatif terhadap Ahl al-Sunnah wa al-Jamā'ah.

Dapat disimpulkan, tema yang dipersembahkan dalam novel ini hanya terbahagi kepada tiga tema. Pertama, mengangkat Syiah Imāmiyyah Ithnā 'Ashariyyah sebagai penyelesai kepada segala permasalahan dan mazhab yang relevan sepanjang zaman. Kedua, mempertikaikan Ahl alSunnah wa al-Jamā'ah sebagai pegangan asli yang diwariskan oleh Nabi SAW dan ketidakrelevanannya menangani pelbagai permasalahan ummah. Ketiga, perbandingan antara kedua-dua pegangan dalam menangani pelbagai isu dan persoalan. 


\section{a. Menolak Keaslian Ahl al-Sunnah wa al-Jamā'ah}

Sebagaimana dinyatakan dalam pendahuluan, pendirian Syiah Imāmiyyah Ithnā 'Ashariyyah terhadap sahabat memberi kesan langsung terhadap pandangan Syiah mengenai mazhab Ahl al-Sunnah wa al-Jamā'ah. Dalam Perempuan Nan Bercinta, menerusi dialog antara Dr. Ali Taqi dan Dr. Tengku Idora, Faisal Tehrani cuba menggambarkan bahawa Ahl al-Sunnah wa al-Jamā'ah yang dianut oleh 90 peratus umat Islam pada hari ini adalah mazhab yang tidak asli berbanding Syiah, mazhab asli yang mewakili sepuluh peratus umat Islam. ${ }^{7}$ Keaslian sesuatu mazhab itu penting kerana ia berhubung rapat dengan kerelevanannya dalam menangani permasalahan umat.

Misalnya, perjuangan menuntut pelbagai hak kaum wanita pada hari ini didakwa berpunca daripada mazhab Ahl al-Sunnah wa al-Jamā'ah yang asas dan dasar hal ehwal wanitanya yang kabur dan tidak mampu menyelesaikan masalah.

"Jika begitu, dalam mazhab ahlul bait, peranan wanita sudah amat kukuh. Apa lagi yang perlu diperjuangkan? Perjuangan yang menuntut bukan-bukan dalam Islam hari ini, berpunca daripada mazhab yang asas dan dasar untuk wanitanya bergantung kepada kesia-siaan. Mengapa tidak meminjam yang terbaik untuk menyelesaikan masalah ummah?", 8

Pandangan Faisal Tehrani tersebut jelas menunjukkan penolakan beliau terhadap keaslian dan keautoritian Ahl alSunnah wa al-Jamā'ah sebagai mazhab yang mampu menyelesaikan permasalahan ummah. Faisal turut mempersoalkan asal kemunculan mazhab Ahl al-Sunnah wa al-Jamā'ah. Ini kerana, mazhab Ahl al-Sunnah wa alJamā'ah hanya wujud terkemudian dengan kelahiran aliran

\footnotetext{
${ }^{7}$ Faisal Tehrani, Perempuan Nan Bercinta, 9.

${ }^{8}$ Ibid., 83.
} 
Ashā'irah yang dipelopori oleh Abū al-Ḥasan al-Ash'ari yang lahir pada kurun ketiga hijrah iaitu pada tahun 260 Hijrah. Sebelumnya tidak pernah wujud aliran yang dinamakan Ahl al-Sunnah wa al-Jamā'ah, sebaliknya yang wujud pada zaman 'Ali adalah pengikut 'Ali yang disebut Syiah 'Ali dan pengikut 'Uthmān yang dinamakan Syiah 'Uthmān.

Setelah perang Jamal, lahir pula kumpulan yang digelar Khawārij. Seterusnya pada zaman Bani Umayyah lahir lebih banyak lagi kumpulan seperti Murji'ah, Qadariyyah, Jabariyyah dan Mu'tazilah. Pada zaman Bani 'Abbāsiyyah, mazhab Mu'tazilah menjadi sangat kukuh kerana ia didukung oleh beberapa orang khalifah iaitu alMa'mūn dan al-Mu'tașim. Namun begitu, akibat penggunaan akal yang semakin melampau dalam pemikiran Mu'tazilah, Abū al-Ḥasan al-Ash'ari yang pada asalnya merupakan bekas tokoh $\mathrm{Mu}$ 'tazilah telah mengisytiharkan diri menolak fahaman $\mathrm{Mu}$ 'tazilah lalu mengajak umat Islam agar kembali kepada sunnah dan jamā'ah. Aliran alAsh'ari ini kemudiannya dikembangkan lagi dengan kemunculan seorang lagi tokoh Ahl al-Sunnah wa alJamā'ah iaitu Abū Manșūr al-Māturīīi. Dari sudut fiqah mereka menerimapakai empat mazhab yang saling bertentangan antara satu dengan lain di samping mengenepikan Mazhab Ja'fari yang dipegang oleh Syiah Imāmiyyah Ithnā 'Ashariyyah. ${ }^{9}$

Justeru, Faisal Tehrani memandang Ahl al-Sunnah wa al-Jamā'ah sebagai sebuah mazhab yang baharu. Ia hanya wujud 200 tahun selepas kewafatan Rasulullah SAW. Landasan kewujudan Ahl al-Sunnah wa al-Jamā'ah juga hanya berasaskan retorika menentang fahaman $\mathrm{Mu}$ 'tazilah yang berleluasa pada era 'Abbāsiyyah. Walaupun ia menjadi dominan di dalam dunia Islam, namun ia sebuah pakatan yang rapuh kerana didasari dengan pelbagai pertembungan teologi yang tidak mesra antara al-Ash'ari

\footnotetext{
${ }^{9}$ Ibid., 70-75.
} 
dan al-Māturīi í seperti persoalan ma 'rifatullāh dan qaḍa' dan qadar. Dalam permasalahan fiqah, turut berlaku pertembungan yang sangat ketara antara empat mazhab. Malah sejarah mencatatkan pada zaman 'Abbāssiyyah pernah terjadi pergaduhan yang melibatkan darah antara penganut empat mazhab. Berlaku perpecahan yang kronik akibat kefanatikan terhadap mazhab pegangan masingmasing. Semua itu merupakan indikator, menunjukkan Ahl al-Sunnah wa al-Jamā' ah adalah pakatan yang rapuh, saling bercakaran dan perlu digantikan dengan mazhab yang benar-benar asli dan berasal daripada Rasulullah SAW. ${ }^{10}$

Khair Izzah juga bersependapat dengan Faisal Tehrani. Beliau mempersoalkan keperibadian Abu alHasan al-Ash'ari yang hanya bertaubat daripada fahaman $\mathrm{Mu}$ 'tazilah pada tahun 310 Hijrah ketika berumur 50 tahun. Ia jarak yang amat jauh dengan zaman Nabi SAW dan para sahabat r.a.h. Apa yang menjadi persoalan, mengapa beliau mengambil masa yang terlalu lama untuk memahami isi kandungan al-Qur'an dan al-Sunnah yang sebenar. Selain itu, tiada jaminan bahawa fahaman baharu yang diisytiharkan oleh al-Ash'ari benar-benar sahih dan haq di sisi Allah SWT. Ini kerana, jika al-Ash'ari seorang yang benar-benar pakar dalam pemahaman al-Qur'an dan alSunnah, maka sudah tentu sejak awal lagi beliau tidak menganut fahaman sesat $\mathrm{Mu}$ 'tazilah. Persoalan lebih besar, kesemua empat tokoh ulama mujtahid dalam fiqah Ahl alSunnah wa al-Jamā'ah lahir lebih awal dan meninggal dunia sebelum kelahiran al-Ash'ari. Ini menggambarkan penganut Sunni seolah-olah berada dalam kesesatan akidah sebelum kemunculan al-Ash'ari dan hanya memberikan tumpuan kepada fiqah sepanjang tempoh itu. ${ }^{11}$

\footnotetext{
${ }^{10}$ Ibid., 338-341.

${ }^{11}$ Khair Izzah, Meniti Titian Kebenaran, 3-5.
} 


\section{b. Istilah Ahl al-Sunnah wa al-Jamā'ah menurut Ulama Syiah}

Pandangan Faisal Tehrani dan Khair Izzah tersebut, selari dengan pemikiran Syiah Imāmiyyah Ithnā 'Ashariyyah yang mempersoalkan awal kemunculan istilah Ahl alSunnah wa al-Jamā'ah. Ibn 'Ațiyyah mengatakan istilah Ahl al-Sunnah wa al-Jamā'ah tidak pernah wujud kecuali selepas kemunculan kerajaan Bani Umayyah. Malah istilah bagi kumpulan yang menyelisihi Ahl al-Sunnah wa alJamā'ah juga tidak wujud sebelum zaman pemerintahan Mu'āwiyah bin Abī Sufyān. Sebaliknya Mu'āwiyah orang pertama yang mencipta istilah tersebut pada tahun yang digelar sebagai 'A'm al-Jamā' $a h .^{12}$

Al-Wirdāni mengatakan Ahl al-Sunnah wa al-Jamā'ah sendiri tidak memiliki jawapan mengenai bila istilah itu muncul dan bila mula-mula akidah Ahl al-Sunnah wa alJamā'ah terzahir. Ini menyebabkan mereka cuba menyandarkannya kepada Rasulullah SAW dan para sahabat bagi melegitimasikan akidah mereka, mengaitkannya dengan sejarah awal Islam dan sekaligus melenyapkan segala keraguan. ${ }^{13}$

Sebaliknya orang yang mula-mula meletakkan batu asas pemikiran Ahl al-Sunnah wa al-Jamā'ah adalah Ahmad bin Hanbal. Kemudian ia diteruskan oleh golongan Ḥanābilah dengan dukungan kuat kerajaan 'Abbāsiyyah selepas zaman al-Ma'mūn yang menganut fahaman Mu'tazilah. Manakala empat tokoh mazhab fiqah terbesar iaitu Abū Hanifah, Mālik dan Shāfi'‘ ${ }^{\bar{i}}$ belum lagi mencadangkan apa-apa berkaitan pemikiran Ahl al-Sunnah wa al-Jamā'ah pada zaman mereka.

12 Ibn 'Ațiyyah, Abhā al-Murād, fì Sharh Mu'tamar 'Ulamā' Baghdād (Beirut: Mu'assasah al-A'lami, 1423H), 2: 136.

13 Șāliḥ al-Wirdānī, Ahl al-Sunnah Sha 'b Allāh al-Mukhtār: Dirāsah fī Fasād 'Aqā'id Ahl al-Sunnah (Kaherah: Maktabah Mabdūli al-Ṣaghìr, 1996), 13. 
Jelasnya, akidah Ahl al-Sunnah wa al-Jamā'ah digagaskan dan berkembang menerusi lima peringkat. Pertama, Ahmad bin Hanbal; kedua, Ashā'irah dan Māturídiyyah; ketiga, Hanābilah; dan keempat, Ibn Taimiyyah. Bahkan kitab-kitab yang dikarang bagi mendukung Ahl al-Sunnah wa al-Jamā'ah lebih bersifat menjawab aliran-aliran lain yang bertentangan dengan mereka. Ini menunjukkan Ahl al-Sunnah wa al-Jamā'ah itu adalah perkara baharu yang datang kemudian dan bersifat ijtihād $\bar{i}$, bukan disyariatkan atau dinaskan secara muktamad. ${ }^{14}$

Al-Tỉjāni pula mengatakan istilah Ahl al-Sunnah wa al-Jamā'ah hanya digagaskan sebagai kontra kepada aliran 'Ali dan pengikutnya. Ia dianggap sebagai punca utama terbahaginya umat Islam kepada Ahl al-Sunnah wa alJamā'ah dan Syiah selepas kewafatan Nabi SAW. Ahl alSunnah wa al-Jamā'ah langsung tidak berpegang dengan walā terhadap para wali Allah SWT dan barā' daripada para musuh Allah SWT. Bahkan menyatakan kesetiaan, kasih sayang dan keredaan terhadap semua para sahabat

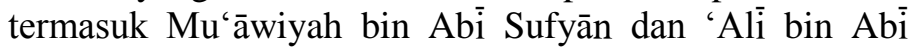
Țālib. Jika penganut Ahl al-Sunnah wa al-Jamā'ah mengetahui bahawa 'Ali itu sebenarnya adalah pintu masuk kepada al-Sunnah al-Nabawiyyah, sudah tentu mereka akan merujuk kembali fahaman mereka. ${ }^{15}$

Dalam karya lain, al-Tījāni mengatakan Ahl al-Sunnah wa al-Jamā'ah telah bersepakat bahawa istilah Ahl alSunnah hanya bermula selepas $\mathrm{Mu}$ 'āwiyah menjadi khalifah pada Am al-Jamā' ah. Ini kerana, selepas kematian 'Uthmān, umat Islam terbahagi kepada pengikut 'Ali dan pengikut $\mathrm{Mu}^{\prime}$ āwiyah. Namun demikian, setelah usaha perdamaian dilakukan antara Hasan dan $\mathrm{Mu}^{\prime}$ āwiyah, $\mathrm{Mu}$ 'āwiyah akhirnya dilantik sebagai khalifah dan sejurus

\footnotetext{
14 Ibid., 19-20.

15 Muhammad al-Tỉjāni, al-Shì 'ah Hum Ahl al-Sunnah (Qom: Markaz al-Abhāâth al-'Aqā'idiyyah, 1427H), 27.
} 
kemudian istilah Ahl al-Sunnah wa al-Jamā'ah menjadi masyhur. Ini menunjukkan, istilah Ahl al-Sunnah wa alJamā'ah merujuk kepada pengikut $\mathrm{Mu}^{\prime}$ āwiyah dan bukan merujuk kepada pengikut Sunnah Nabi SAW. ${ }^{16}$

\section{c. Ahl al-Sunnah wa al-Jamā'ah Mazhab Nawāșib}

Berdasarkan perbahasan di atas, ulama Syiah Imāmiyyah Ithnā 'Ashariyyah cenderung memandang Ahl al-Sunnah wa al-Jamā'ah sebagai mazhab yang diasaskan oleh Mu'āwiyah. Justeru, ia menjadikan Ahl al-Sunnah wa alJamā'ah sebagai kelompok yang sangat ditentang oleh Syiah. Ini kerana, Mu'āwiyah dan kerajaan Bani Umayyah dikategorikan oleh Syiah Imāmiyyah Ithnā 'Ashariyyah sebagai golongan nawāṣib. ${ }^{17}$ Walau bagaimanapun, para ulama Syiah Imāmiyyah Ithnā 'Ashariyyah berselisih pendapat dalam menyandarkan Ahl al-Sunnah wa alJamā'ah kepada nawāṣib.

Pendapat pertama mengatakan, Ahl al-Sunnah wa alJamā'ah itu bukan nawāṣib, namun terdapat dalam kalangan tokoh-tokoh Ahl al-Sunnah yang terjebak dengan perbuatan golongan nawāṣib. ${ }^{18}$ Manakala pendapat kedua pula mengatakan kesemua Ahl al-Sunnah wa al-Jamā'ah itu nawāṣib. ${ }^{19} \mathrm{Ni}$ 'mah Allāh al-Jazā'irì mengatakan, termasuk dalam golongan nawāṣib mereka yang mendahulukan orang lain sebagai imam (khalifah) selain 'Ali. Takrifan ini

${ }^{16}$ Muhammad al-Tỉjānī, Thumm Ihdaytu (London: Mu'assasah al-Fajar, 1991) 204.

17 Muḥsin al-Mu'allim, al-Naṣb wa al-Nawāṣib (Beirut: Dār al-Hudā, 1997), 249; Nawāṣib adalah kata jamak daripada perkataan $n \bar{a} s ̣ i b$ yang bermaksud orang yang menzahirkan permusuhan terhadap 'Ali, ahli keluarganya dan para imam selepas 'Ali dengan mencela mereka, benci untuk menyebut kelebihan mereka atau perbuatan yang seumpama dengannya. Lihat Fakhr al-Din Țarịhi, Majma ' al-Bahrayn (Tehran: Murtadawì, 1416H), 2: 173-174; 'Ali $\overline{\dot{~ A}}$ 'i Muhsin, Li Allāh wa li al-Haqiqah (Tehran: Mash'ar, 1382H), 410.

${ }^{18}$ Badr bin Nāṣir al- 'Awwād, al-Naṣb wa al-Nawāṣib (Riyaḍ: Maktabah Dār al-Minhāj, 1433H), 94.

${ }^{19}$ Ibid., 95. 
disokong dengan perkataan para imam Ahl al-Bayt yang menggelarkan Abū Hanifah dan seumpamanya sebagai $n \bar{a} s i_{i} \bar{i}$ walaupun Abū Hanifah dikenali sebagai orang yang menyayangi Ahl al-Bayt dan tidak memusuhi mereka. ${ }^{20} \bar{A}$ li 'Usfür menyokong pendapat ini dengan menegaskan riwayat-riwayat para imam Ahl al-Bayt menunjukkan nawāṣib itu adalah Ahl al-Sunnah wa al-Jamā'ah tanpa dapat dipertikaikan lagi. ${ }^{21}$

Pendapat kedua yang memasukkan Ahl al-Sunnah wa al-Jamā'ah sebagai kelompok nawāṣib dilihat lebih konsisten di sisi Syiah Imāmiyyah Ithnā 'Ashariyyah. Walaupun terdapat sesetengah riwayat Syiah yang menunjukkan penerimaan terhadap Ahl al-Sunnah wa alJamā'ah dalam ibadat dan pergaulan, namun itu sekadar untuk bertaqiyyah. Antaranya apa yang diriwayatkan daripada Ismā‘ỉ al-Ju'fī yang bertanya kepada Abū Ja'far, Muḥammad al-Bāqir (Imam kelima):

"Seorang lelaki mencintai Amir al-Mu'minin ('Ali), tetapi tidak berlepas diri daripada musuhnya dengan berkata: Dia ("Ali) lebih aku cintai berbanding yang menyelisihinya. AlBāqir menjawab: Ini kekeliruan, dia adalah musuh, jangan kamu solat di belakangnya, tiada penghormatan (untuknya) kecuali kamu bertaqiyyah dengannya."22

${ }^{20} \mathrm{Ni}$ 'mah Allāh al-Jazā'irī, al-Anwār al-Nu 'māniyyah (Beirut: Dār alQāri’, 2008), 2: 211.

21 Husayn bin Muhammad Āli 'Ușfūr, al-Mahāsin al-Nafsāniyyah fī Ajwibah al-Masā'il al-Khurasāniyyah (Beirut: Dār al-Mashriq al'Arabi al-Kabir, 1979), 147.

22 'Alī bin al-Husayn Ibn Bābawayh, Man lā Yahḍuruh al-Faqīh (Qom: M u'assasah al-Nashr al-Islāmí, 1413H), 1: 380; Muḥammad bin alHasan al-Ṭūí, Tahdhīb al-Ahkām (Tehran: Dār al-Kutub alIslāmiyyah, 1407H), 3: 28; Muhammad bin Ḥasan al-Ḥurr al- 'Āmilì, Tafṣil Wasā'il al-Shì'ah ilā Tahșīl Masā'il al-Shari'ah (Qom: Mu'assasah Ahl al-Bayt li Ihyāa al-Turāth, 1409H), 8: 309. 
Selain itu terdapat riwayat yang masyhur mengatakan $n a s ̦ i b \bar{i}$ itu bukan sahaja mereka yang memarahi 'Ali tetapi juga mereka yang membenci pihak yang mendukung 'Ali. Ia sebagaimana yang diriwayatkan daripada Ja'far al-Ṣādiq (Imam Keenam):

"Bukanlah nāṣibi itu orang yang memarahi kami Ahl al-Bayt kerana sesungguhnya kamu tidak akan bertemu orang yang mengatakan: Aku memarahi Muhammad dan keluarga Muhammad. Akan tetapi nāṣibīitu adalah orang yang memarahi kamu sedangkan dia mengetahui sesungguhnya kamu berwalak kepada kami dan sesungguhnya kamu adalah pengikut kami." 23

Berdasarkan riwayat sebegini, sebahagian ulama Syiah Imāmiyyah seperti al-Khājū'i mengatakan sesiapa yang tidak mengakui keimaman para imam Ahl al-Bayt seperti yang dianuti oleh Syiah Imāmiyyah, ia termasuk ke dalam golongan nawāșib. ${ }^{24}$

\section{d. Mazhab majoriti bukan hujah}

Khair Izzah mempertikaikan hujah yang menggunakan kaedah kelompok majoriti itu sentiasa benar. Beliau membawakan beberapa ayat al-Qur'an yang menunjukkan bahawa kumpulan yang ramai itu kebiasaannya paling banyak melakukan kerosakan dan kefasadan seperti yang terkandung dalam surah al-An'ām ayat 116 dan 119, surah Yūnus ayat 36, surah al-Furqān ayat 44, surah al-A'rāf ayat

${ }^{23}$ Muhammad bin 'Ali bin Bābawayh, Thawāb al-A 'māl wa 'Iqāb al$A$ 'māl (Qom: Dār al-Sharif al-Riḍā, 1406H), 207; Muhammad bin Murtaḍa al-Kāshānī, al-Wāfī (Asfahān: Maktabah al-Imām Amīr alMu'minin 'Ali' alayh al-salām, 1406H), 2: 230; al-'Āmili, Wasā'il alShì'ah, 9: 486; Muḥammad Bāqir al-Majlisī, Bihāar al-Anwār alJāmi 'ah lidurar Akhbār al-A 'immah al-Ațhār (Beirut: Dār Ihyā' alTurāth al-'Arabi, 1403H), 8: 369; Țarihị, Majma 'al-Bahrayn, 2: 174.

${ }^{24}$ Muhammad bin Ismā' 'ìl al-Khājū' $\bar{i}$, al-Rasā'il al-Fiqhiyyah (Qom: Dār al-Kutub al-Islāmi, 1411H), 2: 100. 
102 dan surah Șād ayat 24. Sebaliknya Allah SWT sering merujuk kumpulan yang benar-benar beriman itu sebagai kumpulan minoriti seperti yang terkandung dalam surah Nūḥ ayat 40, surah Saba' ayat 13 dan surah Șād ayat 24 . Justeru, bilangan tidak penting dalam menilai kebenaran sesuatu ajaran. ${ }^{25}$ Dengan kerangka pemikiran yang sama, Syiah Imāmiyyah Ithnā 'Ashariyyah menolak hadis masyhur yang mengatakan bahawa Rasulullah SAW bersabda, "Hendaklah kamu bersama dengan kehitaman yang besar (majoriti umat)."26

Menurut al-Najafí, hadis ini langsung tidak boleh dijadikan hujah memandangkan ia hanya bersifat zanni atau andaian sedangkan dalam surah Yūnus ayat 36, Allah SWT berfirman, "Sesungguhnya zann (persangkaan) itu tidak sedikit pun berguna untuk mencapai kebenaran..." Hadis itu juga bertentangan dengan surah Āli 'Imrān ayat 144, "Adakah jika dia (Rasulullah SAW) wafat atau dibunuh kamu berbalik semula ke belakang (murtad)?", yang menunjukkan bahawa majoriti umat Islam akan kembali semula kepada sepertimana zaman jahiliyyah mereka selepas kewafatan Rasulullah SAW. ${ }^{27}$

Begitu juga hadis al-Hawd yang menggambarkan majoriti sahabat telah murtad selepas kewafatan Rasulullah SAW sehingga tidak dibenarkan meminum air telaga alKawthar yang disediakan untuk umat Nabi SAW di akhirat kelak. Di samping itu, banyak ayat al-Qur'an yang mengisahkan sedikitnya umat terdahulu yang beriman kepada para nabi yang diutuskan, sebaliknya majoriti terus berada dalam kekufuran dan kesesatan. ${ }^{28}$ Qāḍi Nūr Allāh

${ }^{25}$ Khair Izzah, Meniti Titian Kebenaran, 13-16.

${ }^{26}$ Hadis riwayat Ibn Mājah, Kitāb al-Fitan, Bāb al-Sawād al-A'ẓam, no. hadis: 3950. Lihat Muhammad bin Yazìd, Sunan Ibn Mājah (Beirut: Dār al-Fikr, t.t), 2: 1303.

${ }^{27}$ Muhammad Hasan al-Muẓaffar al-Najafī, Dalā'il al-Ṣidq li Nahj alHaq (Qom: Mu'assasah Āl al-Bayt, 1422H), 3: 201-202.

${ }^{28}$ Ibid. 
pula mengatakan al-sawād al-a'zam bukan bermaksud majoriti umat seperti yang difahami oleh Ahl al-Sunnah wa al-Jamā'ah, sebaliknya ia bererti apa yang ditinggalkan oleh Nabi SAW kepada umatnya berupa al-Qur'an dan ahli keluarga Baginda (Ahl al-Bayt). ${ }^{29}$

Syiah Imāmiyyah Ithnā 'Ashariyyah turut berpandangan, isu majoriti tidak boleh dijadikan hujah kerana ia tidak konsisten dengan apa yang berlaku pada zaman para sahabat sendiri. Ini kerana, Ahl al-Sunnah wa al-Jamā'ah menerima pelantikan Abū Bakr sebagai khalifah atas dasar ia disokong majoriti para sahabat, namun dalam kes pembunuhan 'Uthmān yang disokong oleh majoriti sahabat, Ahl al-Sunnah wa al-Jamā'ah tidak pula menolak 'Uthmān sebaliknya tetap meletakkan 'Uthmān pada kedudukan yang tinggi. Kerana itu, Allah SWT tidak pernah menjadikan majoriti sebagai penilaian terhadap kebenaran. Malah, golongan Bani Israel secara majoritinya telah mengingkari Nabi Hārūn dan menyembah patung anak lembu ketika ketiadaan Nabi Mūsā.

Hal ini juga akan terjadi kepada umat Nabi Muhammad SAW sebagaimana sabda Baginda, "Akan berlaku pada umat ini apa yang berlaku pada umat terdahulu umpama selipar dengan selipar (persamaan yang tidak berbeza sama sekali)." Justeru, dalam al-Qur'an Allah SWT banyak memuji golongan yang sedikit berbanding dengan golongan yang majoriti tetapi ingkar dan melanggar perintah-Nya sepertimana firman Allah SWT dalam surah Saba' ayat 13, "Dan amat sedikit daripada kalangan hamba-Ku yang bersyukur."30

Walau bagaimanapun, mazhab Ahl al-Sunnah wa alJamā'ah terus berkembang hasil daripada campur tangan politik pemerintah sebagaimana pendapat Sayyid Murtaḍa

${ }^{29}$ Qāḍi Nūr Allāh al-Mar'ashī, Ihqāq al-Haq wa Izhāq al-Bātil (Qom: Maktabah Āyat Allāh al-Mar'ashī al-Najafï, 1409H), 2: 61-62.

${ }^{30}$ Sayyid 'Abd Allāh Shibr, Haq al-Yaqīn fī Ma 'rifah Ușūl al-Dīn (Qom: Anwār al-Hudā, 1424H), 266. 
al-'Askari. Ini kerana, majoriti para pemerintah, apabila melihat sesuatu perkara itu menepati kepentingan politik mereka, maka ia akan diperakukan. Sumber pertama yang dieksploitasikan adalah al-Qur'an agar menepati kepentingan mereka. Kedua, hadis-hadis yang mendukung fahaman mereka. Kemudian, apa yang dianut oleh pemerintah akan menjadi undang-undang yang dipraktikkan secara rasmi di dalam negara. Apa jua yang menyalahinya akan disekat dan dihukum dengan keras termasuk hukuman mati. Akhirnya pemerintah akan memaksa supaya umat mengambil fatwa-fatwa daripada mazhab empat dalam fiqah dan pandangan-pandangan alAsh'ari dalam akidah. ${ }^{31}$

Pandangan yang sama diketengahkan oleh Faisal Tehrani dalam novel provokatifnya. Beliau menyelitkan mesej yang mengandungi elemen menyeru kepada penentangan terhadap pemerintah Ahl al-Sunnah wa alJamā'ah sedia ada menerusi slogan "revolusi kebudayaan". Revolusi tersebut mengajak umat Islam kembali kepada pedoman Ahl al-Bayt menurut fahaman Syiah Imāmiyyah Ithnā 'Ashariyyah. ${ }^{32}$ Beliau menyeru supaya menentang penubuhan institusi atau agensi yang bertanggungjawab ke atas hal ehwal agama secara rasmi. Ia didakwa menyempitkan pengertian agama kepada kelompok tertentu sahaja sedangkan yang lain dianggap salah dan perlu disekat.

Penginstitusian juga mendorong agama menjadi hak milik manusia dalam mentafsirkan al-Qur'an dan alSunnah menurut aliran sendiri. ${ }^{33}$ Penggunaan hujah sadd al-dhara ' $\bar{i}$ ' dan al-akhdh bi al-ahwwat juga dibidas kerana ia sekadar alasan pemerintah untuk menghalalkan tindakan mereka. Walhal tujuan sebenar adalah untuk memaksakan

\footnotetext{
${ }^{31}$ Șālih al-Wirdāni, al-Shì 'ah fī Miṣr: Min al-Imām 'Alī hattā al-Imām al-Khumaynī (Kaherah: Maktabah Madbūlī al-Șaghïr, 1993), 12.

${ }^{32}$ Faisal Tehrani, Perempuan Nan Bercinta, 112.

${ }^{33}$ Ibid., 179-180.
} 
satu mazhab sahaja diamalkan bagi memastikan kedudukan mereka tidak tergugat. ${ }^{34}$

Kesimpulannya, karya-karya Syiah berbahasa Melayu berpendapat Ahl al-Sunnah wa al-Jamā'ah sebagai mazhab yang wujud terkemudian dan jauh sekali perkaitannya dengan Rasulullah SAW dan sunnahnya. Paling awal kemunculan Ahl al-Sunnah wa al-Jamā'ah disebut berlaku pada zaman $\mathrm{Mu}$ 'āwiyah dan selewatnya pada zaman Abū al-Hasan al-Ash'ari. Sebagaimana yang disifatkan oleh alHilli, Ahl al-Sunnah wa al-Jamā'ah adalah mazhab baharu yang terputus daripada Rasulullah SAW dan para sahabat. Ini kerana, mereka menerima pakai qiyās dan penggunaan akal, lalu memasukkan ke dalam agama Allah apa yang bukan daripadanya, menyelewengkan hukum-hakam syariah dan mencipta mazhab empat yang tidak pernah wujud pada zaman Rasulullah SAW dan para sahabat. ${ }^{35}$

\section{Perbandingan Antara Keaslian Ahl al-Sunnah wa al- Jamā'ah dan Syiah}

Pendirian Syiah Imāmiyyah Ithnā 'Ashariyyah yang menolak keaslian mazhab Ahl al-Sunnah wa al-Jamā'ah merupakan suatu persepsi yang sengaja diada-adakan. Mereka bersikap tidak adil dalam menilai asal usul kemunculan Ahl al-Sunnah wa al-Jamā'ah. Penekanan seharusnya diberikan kepada aspek manhaj atau metodologi dan bukan semata-mata kepada tokoh dan istilah yang merujuk kepada aliran tersebut. Sementelah kemunculan Syiah Imāmiyyah Ithnā 'Ashariyyah sendiri tidak memiliki asas yang kukuh pada zaman Rasulullah SAW. Menurut al-Musawi, bibit-bibit kemunculan Syiah

\footnotetext{
${ }^{34}$ Ibid., 384.

35 Beliau adalah Jamāl al-Dīn al-Hasan bin Yūsuf bin 'Alì bin alMuțahhir al-Hilli. Seorang ulama fiqah dan mutakallim Syiah Imāmiyyah pada kurun ke-7 hijrah. Meninggal dunia pada tahun 726H. Lihat Khayr al-Dīn al-Zirkili, al-A 'lām (Beirut: Dār al-'Ilm li al-Malāyīn, 1992), 2: 227; al-Hasan bin 'Alì al-Hilli, al-Rijāl (Najaf: Manshūrāt al-Maṭba'ah al-Ḥaydariyyah, 1972), 78.
} 
hanya bermula selepas kewafatan Rasulullah SAW ketika umat Islam saling mencadangkan pengganti Rasulullah SAW sebagai khalifah. ${ }^{36}$

Malah al-Musawi mengatakan, Syiah dengan kepercayaan-kepercayaan yang pelik seperti dakwaan pelantikan 'Ali dengan nas, pelanggaran para sahabat terhadap nas kecuali beberapa orang dan doktrin imāmāh sebagai pelengkap rukun Islam, hanya timbul selepas berlaku keghaiban besar al-Mahdi pada tahun 329 Hijrah. ${ }^{37}$ Hal ini juga diperakui oleh salah seorang tokoh Syiah Imāmiyyah Ithnā 'Ashariyyah, Āl al-Kāshif al-Ghitā' yang berpandangan, tiada keperluan untuk Syiah menzahirkan diri sejurus selepas kewafatan Rasulullah SAW kerana umat Islam masih berada di atas manhaj yang lurus sehingga terjadi perang Șiffīn antara 'Alì dan Mu'āwiyah. ${ }^{38}$ Jika selepas kewafatan Rasulullah SAW pun tiada keperluan untuk Syiah menzahirkan diri, apa lagi sebelum kewafatan Rasulullah SAW. Menunjukkan Syiah itu sememangnya suatu ajaran baharu yang dicipta kemudian.

Dengan demikian, ramai sarjana yang berteori bahawa peristiwa perang Șiffīn menjadi punca kepada kelahiran kumpulan Syiah. Menurut Iḥsān Ilāhī Zāhir, pandangan ini dipegang oleh Ibn Hazm dan Ahmad Amin serta beberapa penulis Syiah seperti al-Khawansāri di dalam kitabnya Rawdàt al-Jannāt ${ }^{39}$. Pandangan ini lebih tepat memandangkan selepas perang Șiffīn, kumpulan Khawārij

${ }^{36}$ Mūsā al-Musawì, al-Shì 'ah wa al-Tașhịh: al-Ṣirā 'bayn al-Shì' ah wa al-Tashayyu' ('Ammān: Dār 'Ammār, 1998), 11-12.

${ }^{37}$ Ibid., 14-15.

38 Muhammad al-Ḥusayn Āl al-Kāshif al-Ghitā', Aṣl al-Shī'ah wa Ușūluha: Muqāranah ma' al-Madhāhib al-Arba'ah (Beirut: Dār alAḍā', 1990), 124.

${ }^{39}$ Iḥsān Ilāhī Zāhir, al-Shì ‘ah wa al-Tashayyu ' (Lahore: Dar Tarjuman al-Sunnah, 1984), 13; Abū Muhammad bin Hazm, al-Fișal fī al-Milal wa al-Ahwā' wa al-Nihal (Kaherah: Maktabah al-Khānjì, t.t), 4: 79; Aḥmad Amīn, Fajr al-Islām (Kaherah: Maktabah al-Nahḍah, 1965), 266. 
telah keluar daripada mentaati 'Ali dan membina gerakan mereka sendiri di Nahrawān. Sebagai tindak balas kepada kumpulan Khawārij, penyokong 'Alì semakin berkembang dari semasa ke semasa sehingga membentuk satu fahaman politik. Bermula dari sini, Syiah berpindah menjadi sebuah kumpulan yang melampau dan fanatik terhadap 'Ali sehingga ke peringkat mencela, mengkafirkan dan berlepas diri daripada para sahabat r.a.h kecuali beberapa orang seperti Salmān al-Fārisìi, Abū Dhar, al-Miqdād, 'Ammār bin Yāsir dan Hudhayfah r.a ${ }^{40}$.

Pertikaian yang lebih mendasar apabila ia melibatkan keabsahan dua belas orang imam yang menjadi asas kepada mazhab Syiah Imāmiyyah Ithnā 'Ashariyyah sendiri. Wujud keraguan terhadap kelahiran imam kedua belas Syiah Imāmiyyah Ithnā 'Ashariyyah yang sekaligus boleh menafikan keaslian mazhab tersebut. Sebahagian karya Syiah memperakui bahawa imam yang kesebelas, iaitu alHasan al-'Askari merupakan seorang yang mandul. Diriwayatkan ketika kematian beliau pada tahun 260 Hijrah, kaum kerabatnya telah memeriksa sama ada terdapat dalam kalangan isteri atau hamba sahayanya yang mengandung. Namun, tiada seorang pun yang mengandung menyebabkan harta pusaka beliau dibahagikan kepada ibu dan saudara lelakinya, Ja'far. Pihak khalifah juga telah menghantar wakil ke rumah al-Ḥasan al-'Askari untuk menyiasat isteri-isteri atau hamba-hamba sahayanya, namun didapati beliau langsung tidak memiliki anak. ${ }^{41}$

Salah seorang tokoh besar Syiah, al-Mufīd mengatakan al-Ḥasan tidak memiliki seorang pun anak

${ }^{40}$ Ghālib bin 'Alì 'Awwājì, Firaq Mu'âșirat Tantasib Ilā al-Islām wa Bayān Mawqif al-Islām minhā (Jeddah : al-Maktabah al-'Așriyyah alDhahabiyyah, 2001), 1: 311-312.

41 Muhammad bin Ya'qūb al-Kulayni, al-Kāfī (Qom: Dār al-Hadīth, 1429H), 1: 505; al-Kāshāni, al-Wāfìi, 3: 846; al-Baḥrāni, Hilyah alAbrār, 6: 97. 
sewaktu hayat mahupun setelah kematiannya. ${ }^{42}$ Hal yang sama turut dinukilkan oleh al-Nawbakhti ketika menghuraikan mengenai pecahan-pecahan kumpulan Syiah. Menurut beliau, selepas kematian al-Hasan bin 'Ali, Syiah Imāmiyyah berpecah kepada tiga belas kumpulan. Daripada tiga belas kumpulan tersebut, hanya tiga kumpulan yang berpendapat bahawa al-Hasan ada meninggalkan zuriat selepas kematiannya. ${ }^{43}$ Fakta-fakta di atas menunjukkan bilangan para imam Syiah Imāmiyyah Ithnā 'Ashariyyah tidak mencapai dua belas orang secara muktamad. Ini kerana, imam yang kedua belas dipertikaikan kewujudannya oleh sebahagian besar penganut Syiah Imāmiyyah sendiri. Implikasinya, keaslian Syiah Imāmiyyah Ithnā 'Ashariyyah sebagai sebuah mazhab yang dimaksudkan oleh Rasulullah SAW dalam hadis dua belas khalifah boleh diragui. ${ }^{44}$

Dalam masa yang sama, doktrin pegangan Syiah Imāmiyyah Ithnā 'Ashariyyah didapati lebih hampir kepada doktrin yang pertama kali diperkenalkan oleh kelompok Saba'iyyah pada zaman 'Ali menjadi khalifah. Saba'iyyah merupakan kumpulan Syiah pertama yang diasaskan oleh 'Abd Allāh bin Saba' ${ }^{45}$ Kewujudan Ibn Saba' disebut dan diperakui oleh para ulama Syiah sendiri. Antaranya alQummi dan al-Nawbakhti yang berpendapat bahawa Ibn Saba' merupakan orang terawal yang mendakwa 'Ali sebagai wași kepada Nabi SAW.

${ }^{42}$ Al-Mufīd, al-Irshād, 2: 336; 'Alì bin 'Īsā al-Irbili, Kashf al-Ghummah (Beirut: Dār al-Aḍ̂ā', 1985), 3: 211.

43 Al-Hasan bin Mūsā Nawbakhti, Firaq al-Shī'ah (Istanbul: Maṭba'ah al-Dawlah, 1931), 79-93.

${ }^{44}$ Hadis riwayat al-Bukhārī, Kitāb al-Ahkām, Bāb al-Istikhlāf, no. hadis: 6796. Lihat Muhammad bin Ismā'‘il al-Bukhārì, al-Jāmi ‘ al-Sahīh ālMukhtașar (Beirut: Ibn Kathïr, 1987), 6: 2640; Muslim, Kitāb alImārah, Bāb al-Istikhlāf wa Tarkuh, no. hadis: 1821. Lihat Muslim bin al-Hajjāj, Șahịh Muslim (Beirut: Dār Ihyā̄' al-Turāth al-'Arabī, t.t.), 3: 1452 .

45 Muhammad bin 'Abd al-Karīm al-Shahrastānī, al-Milal wa al-Nihal (Beirut: Dār al-Ma'rifah, 1404h), 1: 174. 
Doktrin tersebut diambil ketika beliau masih beragama Yahudi yang mempercayai Yushā' bin Nūn adalah wași kepada Nabi Mūsā a.s. Ibn Saba’ juga orang pertama yang menzahirkan cacian terhadap Abū Bakr, 'Umar dan 'Uthmān serta berlepas diri daripada mereka sambil mendakwa ia diarahkan oleh 'Ali. Ketika mendengar kematian 'Ali, Ibn Saba' mendakwa beliau belum meninggal dunia sebaliknya akan kembali semula pada suatu masa nanti. ${ }^{46}$ Kesemua doktrin tersebut memiliki banyak persamaan pada asasnya dengan pegangan Syiah Imāmiyyah Ithnā 'Ashariyyah yang percaya terhadap pelantikan 'Ali secara nas dan wasiat, raj' $a h$ atau kembalinya para imam ke dunia dan penolakan terhadap majoriti sahabat. Jika sedemikian, bagaimana mungkin untuk mengaitkan Syiah Imāmiyyah Ithnā 'Ashariyyah sebagai mazhab yang berasal daripada Ahl alBayt?

\section{Dakwaan Ahl al-Sunnah wa al-Jamā'ah sebagai Mazhab Baharu}

Dakwaan Khair Izzah dan Faisal Tehrani bahawa Ahl alSunnah wa al-Jamā'ah hanya wujud selepas kemunculan Abū al-Hasan al-Ash'ari merupakan suatu kesalahfahaman. Ini kerana, terdapat tiga perbahasan yang perlu difahami dalam membahaskan istilah Ahl al-Sunnah wa al-Jamā'ah. Pertama, sandaran syarak terhadap istilah al-Sunnah dan alJamā'ah. Kedua, awal penggunaan istilah Ahl al-Sunnah wa al-Jamā'ah. Ketiga, Ahl al-Sunnah wa al-Jamā'ah sebagai sebuah mazhab akidah dan fiqh.

\section{i. Sandaran Istilah Ahl al-Sunnah wa al-Jamā'ah Menurut Syarak}

Berkenaan istilah al-Sunnah dan al-Jamā'ah, ia sabit berdasarkan nas syarak yang banyak. Bagi istilah alSunnah, Rasulullah SAW pernah mengungkapkannya

46 Sa'd bin 'Abd Allāh al-Qummi, al-Maqālāt wa al-Firaq (Tehran: Maṭba'ah Haydari, 1963), 20; al-Nawbakhtí, Firaq al-Shi' 'ah, 22. 
dengan makna wahyu yang selain daripada al-Qur'an. Baginda SAW bersabda:

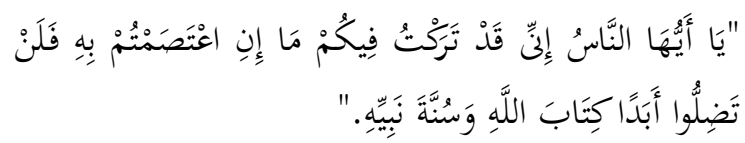

Terjemahan:

"Wahai sekalian manusia, sesungguhnya aku telah tinggalkan buat kamu (dua perkara) selagimana kamu berpegang dengannya, maka kamu tidak akan sesat selama-lamanya, iaitu Kitabullah dan sunnah Nabi-Nya."47

Istilah al-Sunnah juga digunakan untuk merujuk kepada perkara yang mempunyai dalil syarak, sama ada daripada al-Qur'an mahupun sunnah Rasulullah SAW dan ijtihad para sahabat. Antaranya sabda Baginda SAW:

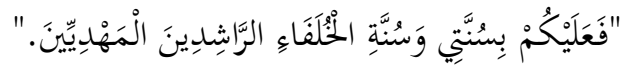

Terjemahan:

"Hendaklah kamu mengikuti sunnahku dan sunnah para Khulafā' al-Rāshidīn alMahdiyyin." 48

${ }^{47}$ Hadis riwayat al-Bayhaqī, Kitāb Ādāb al-Qāḍi, Bāb Mā Yaqụi bin alQāḍi wa Yuftī bih al-Muftí.., no. hadis: 20123. Lihat Abū Bakr alBayhaqi, Sunan al-Bayhaqi al-Kubrā (Makkah al-Mukarramah: Maktabah Dār al-Bāz, 1994), 10: 114; hadis Mālik bin Anas, Kitāb alQadr, Bāb al-Nahy 'an al-Qawl bi al-Qadr, no. hadis: 1594. Lihat alMuwatța' (Mesir: Dār Ihyā̄' al-Turāth al'Arabī, t.t), 2: 899. Menurut Ibn 'Abd al-Barr, hadis ini terpelihara, dimaklumi dan masyhur dalam kalangan ahli ilmu sehingga ia hampir tidak perlu kepada sanad. Lihat Yūsuf bin 'Abd Allāh bin 'Abd al-Barr, al-Tamhìd fï al-Muwațta' min al-Ma 'àni wa al-Asānìd (Maghrib: Wizārah 'Umūm al-Awqāf wa alShu'ūn al-Islāmiyyah, 1387H),24: 331.

${ }^{48}$ Hadis riwayat al-Tirmidhi, Kitāb al-'Ilm 'an Rasūlillāh, Bāb Mā Jā' fī al-Akhdh bi al-Sunnah wa Ijtināb al-Bida', no. hadis: 2676. Lihat Muhammad bin 'Īsā, al-Jāmi ' al-Șaḥihh (Beirut: Dār Ihyā' al-Turāth al-'Arabi, t.t), 5: 44. Al-Tirmídhi mengatakan hadis ini hasan șahịh. 
Pada ketika yang lain, al-Sunnah diucapkan oleh Rasulullah SAW bagi menyerlahkan maksud lawan kepada bid'ah yang dilarang. Antaranya hadis yang menegah tiga orang sahabat yang berhasrat untuk bersolat sepanjang malam, berpuasa sepanjang tahun dan menegah diri daripada berkahwin. Baginda SAW lalu bersabda:

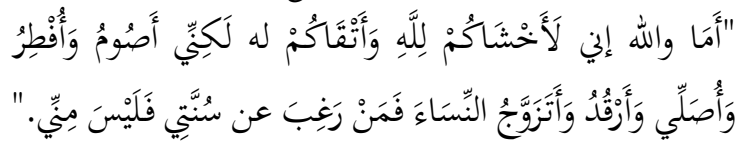

Terjemahan:

"Adapun demi Allah, sesungguhnya aku orang yang paling takut kepada Allah dalam kalangan kamu, paling bertaqwa dalam kalangan kamu kepada-Nya, namun begitu, aku berpuasa dan berbuka, bersolat dan tidur dan mengahwini wanita. Maka sesiapa yang membenci sunnahku, ia bukan daripada kalanganku." 49

Demikian juga hadis Rasulullah SAW mengenai golongan yang menunggu bintang-bintang muncul sebagai waktu berbuka puasa ${ }^{50}$ menerusi sabdanya:

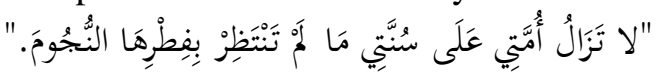

Terjemahan:

"Umatku sentiasa berpegang dengan sunnahku selagi mana ia tidak menunggu bintang-bintang keluar untuk membuka puasanya." 51

${ }^{49}$ Hadis riwayat al-Bukhārī, Kitāb al-Nikāḥ, Bāb al-Targhīb fī al-Nikāḥ, no. hadis: 4776. Lihat al-Jāmi' al-Ṣahịh āl-Mukhtașar, 5: 1949.

${ }^{50}$ Menurut Ibn Daqiq al-' $\bar{I} d$, hadis ini menjadi dalil penolakan terhadap fahaman Shi'ah yang melewatkan waktu berbuka puasa sehingga munculnya bintang-bintang. Lihat Ahmad bin 'Ali bin Hajar al'Asqalānī, Fatḥ al-Bārì Sharḥ Șaḥịh al-Bukhārī (Beirut: Dār Ma'rifah, t.t), 4: 199.

${ }^{51}$ Hadis riyawat Ibn Hibbān, Zikr al-Khabar al-Mudhị̣ Qawl Man Abțal Murā‘āh al-Awqāt li Adā’ al-Ṭā‘āt bi al-Hiyal wa al-Asbāb, no. hadis: 3510. Lihat Muḥammad bin Hibban, Șahịh ibn Hibbān bi tartīb Ibn Balbān (Beirut: Mu'assasah al-Risālah, 1993), 8: 277. 
Berpandukan dalil-dalil tersebut, jelas menunjukkan perkataan al-Sunnah bukan istilah yang datang kemudian, sebaliknya ia bersumberkan lisan Rasulullah SAW sendiri. Walaupun istilah tersebut tidak terkandung dalam alQur'an, namun begitu, terdapat konotasi al-Sunnah yang jelas dalam setiap ayat yang merujuk kepada perintah mengikuti Rasulullah SAW sama ada berbentuk suruhan ataupun larangan. Antaranya, firman Allah SWT dalam surah al-Hashr ayat 7:

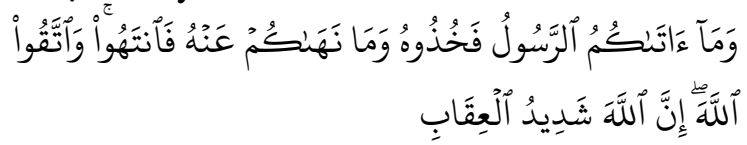

Terjemahan:

"Dan apa jua perintah yang dibawa oleh Rasulullah (SAW) kepada kamu maka terimalah serta amalkan, dan apa jua yang dilarang-Nya kamu melakukannya maka patuhilah larangan-Nya, dan bertaqwalah kamu kepada Allah; Sesungguhnya Allah amatlah berat azab seksa-Nya (bagi orang yang melanggar perintah-Nya)."

Adapun istilah al-Jamā'ah, ia kerap kali digunakan oleh Rasulullah SAW dalam hadis-hadis Baginda. Hadis yang paling masyhur adalah sabda Baginda:

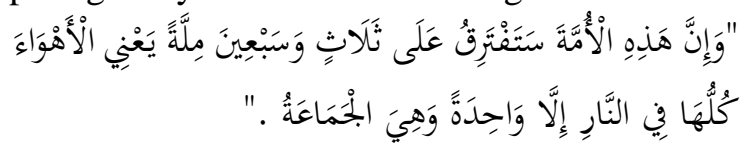

Terjemahan:

"Dan sesungguhnya umat ini akan berpecah kepada tujuh puluh tiga golongan (mengikut hawa nafsu), semuanya di dalam neraka kecuali satu iaitu al-Jamā'ah." ${ }^{52}$

${ }^{52}$ Hadis riwayat Ibn Mājah, Kitāb al-Fitan, Bāb Iftirāq al-Ummah, no. hadis: 3993. Lihat Sunan Ibn Mājah, 2: 1322: Aḥmad, Musnad al- 
Berdasarkan hadis ini dan beberapa hadis lain, para ulama telah menjelaskan siapakah golongan yang dimaksudkan dengan al-Jamā'ah tersebut. Menurut alShāțibi, pada umumnya pendapat para ulama mengenai alJamā'ah berkisar kepada beberapa pengertian. Pertama, ia bererti golongan majoriti dalam kalangan umat Islam yang terdiri daripada imam mujtahid, para ulama dan ahli syariah dan umat yang mengikuti mereka. Sebahagian hadis menyebut mereka sebagai al-sawād al-a'zam. Kedua, kumpulan para ulama mujtahid. Ketiga, para sahabat Rasulullah SAW. Keempat, umat Islam yang bersepakat atau berijmak atas sesuatu perkara. Ia juga kembali kepada golongan pertama atau kedua. Kelima, umat Islam yang bersatu mentaati seorang pemimpin. ${ }^{53}$

Setelah menukilkan pendapat-pendapat tersebut, beliau merumuskan bahawa apa yang dimaksudkan dengan al-Jamā'ah adalah merujuk kepada perhimpunan yang bersatu di bawah pemimpin atau imam yang menepati petunjuk al-Qur'an dan al-Sunnah. ${ }^{54}$ Ini jelas menunjukkan bahawa perhimpunan ramai yang bersatu bukan atas dasar kedua-duanya adalah terkeluar daripada apa yang dimaksudkan dengan al-Jamā'ah. Dengan kata lain, seandainya sesebuah kumpulan yang ramai itu tidak berada di atas petunjuk al-Qur'an dan al-Sunnah, maka ia tidak boleh dikategorikan sebagai al-Jamā'ah.

Sebagaimana ungkapan Ibn Mas'ūd, "Al-Jamā'ah adalah apa yang menepati kebenaran, sekalipun engkau berseorangan." 55 Walau bagaimanapun, ungkapan Ibn

Shāmiyyīn, no. hadis: 16979. Lihat Aḥmad bin Hanbal, Musnad alImām Aḥmad, (Kaherah: Mu'assasah Qarțabah, 2011), 4: 102. Shu'ayb al-Arna'ūt mengatakan hadis ini hasan dan ia șaḥih dengan shawāhid yang lain.

${ }^{53}$ Abū Isḥāq al-Shātibi, al-I'tiṣām (Mesir: al-Maktabah al-Tijāriyyah alKubrā, t.t), 2: 260-265.

${ }^{54}$ Ibid., 265.

55 Shams al-Dīn Muhammad bin Abī Bakr bin Qayyim, I'lām alMuwaqqi 'in 'an Rabb al- 'Álamin (Beirut: Dār al-Jîl, 1973) 3: 397. 
Mas' $\bar{u} d$ tersebut dalam konteks sekiranya majoriti umat Islam benar-benar telah rosak dan terkeluar daripada mengikuti manhaj generasi terdahulu yang masih kekal di atas kebenaran. ${ }^{56}$

Hal ini mustahil berlaku apabila melibatkan kesepakatan para ulama mujtahid dalam kalangan umat Muhammad SAW seperti mana sabda Baginda, "Umatku tidak akan bersepakat atas kesesatan." ${ }^{\circ 7}$ Hadis ini menjadi dalil ke atas keautoritian ijmak para ulama sebagai salah satu daripada sumber hukum yang muktabar di sisi Ahl alSunnah wa al-Jamā'ah. ${ }^{58}$ Justeru, kenyataan Syiah Imāmiyyah Ithnā 'Ashariyyah yang mendakwa Ahl alSunnah wa al-Jamā'ah menjadikan bilangan majoriti semata-mata sebagai hujah kebenaran sesuatu golongan adalah tidak benar. Ini kerana, Ahl al-Sunnah wa alJamā'ah tidak mengambil kira bilangan majoriti sekiranya ia bertentangan dengan petunjuk al-Qur'an dan al-Sunnah dan tidak diwakili oleh para ulama mujtahid.

\section{ii. Awal Penggunaan Istilah Ahl al-Sunnah wa al- Jamā'ah}

Mengenai penggunaan terawal istilah Ahl al-Sunnah wa alJamā'ah, ia didapati telah wujud sejak zaman para sahabat. Ini terbukti menerusi tafsiran Ibn 'Abbās terhadap surah Āli

56 Ibid.

${ }^{57}$ Hadis riwayat Ahmad, Musnad al-Qabā'il, no. hadis: 27267. Lihat Musnad al-Imām Ahmad, 6: 396. Shu'ayb al-Arna'ūt mengatakan hadis ini șahịh li ghayrih; Al-Sakhāwi, selepas membentangkan țuruq hadis ini berserta sanadnya mengatakan, "Secara keseluruhan, ia adalah hadis yang masyhur matannya, memiliki sanad yang banyak dan shawāhid yang pelbagai pada (hadis yang) marfū' dan selainnya." Lihat Abū al-Khayr al-Sakhāwī, al-Maqāṣid al-Hasanah fi Bayān Kathīr min al-Ahāāìth al-Mushtaharah 'alā al-Alsinah (Beirut: Dār al-Kitāb al-'Arabi, 1405H), 717.

${ }^{58}$ Abū Bakr al-Khațīb al-Baghdādi , al-Faqīh wa al-Mutafaqqih (Saudi: Dār Ibn al-Jawzì, 1421H), 1: 408-410; Abū Ishāq al-Shïrāzī, al-Luma ‘ fī Ușūl al-Fiqh (Beirut: Dār al-Kutub al-'Ilmiyyah, 1985), 89; Manșūr bin Muhammad al-Sam‘āni, Qawāṭi ‘ al-Adillah fí al-Ușūl (Beirut: Dar al-Kutub al-'Ilmiyyah, 1997), 1: 424. 
'Imrān ayat 106, "(Ingatlah akan) hari (kiamat yang padanya) ada muka (orang-orang) menjadi putih berseri". Al-Jurjānì (w. 345H) ${ }^{59}$, al-Ājiri (w. 360H) ${ }^{60}$ dan al-Lālikā'i (w. $418 \mathrm{H})^{61}$ menukilkan sanad daripada Ibn 'Abbās bahawa maksud, "muka (orang-orang) menjadi putih berseri", adalah penganut Ahl al-Sunnah wa al-Jamā'ah. Ini bererti, orang pertama yang menggunakan istilah Ahl al-Sunnah wa al-Jamā'ah adalah Ibn 'Abbās, seorang tokoh sahabat yang berketurunan Ahl al-Bayt atau Bani Hāshim.

Penggunaannya juga semakin meluas pada zaman salafussoleh sebelum kemunculan Ahmad bin Hanbal dan Abū al-Hasan al-Ash'arì. Antara para ulama salaf yang didapati telah pun menggunakan istilah Ahl al-Sunnah wa al-Jamā'ah sebelum kemunculan Abū al-Hasan al-Ash'ari adalah Ayyūb al-Sukhtiyānī (w. 131H). Beliau pernah berkata, "Aku diberitahu mengenai kematian seorang lelaki dalam kalangan Ahl al-Sunnah, (saat itu) aku merasa seakan-akan kehilangan sebahagian anggota tubuhku." Seorang lagi ulama salaf iaitu Sufyān al-Thawrì (w. 161H) yang pernah dinukilkan perkataannya mengenai Ahl alSunnah wa al-Jamā'ah. Beliau berkata, "Berpesanpesanlah dengan Ahl al-Sunnah dengan kebaikan, sesungguhnya mereka itu asing." Di tempat lain beliau berkata, "Betapa sedikitnya Ahl al-Sunnah wa alJamā'ah." 63

${ }^{59}$ Hamzah bin Yūsuf al-Jurjāni, Tārīkh Jurjān (Beirut: Ālam al-Kutub, 1981), 132.

60 Muhammad bin al-Ḥusayn al-Ājurrī, al-Sharī'ah (Riyāḍ: Dār alWațan, 1999), 5: 2562.

61 Hibah Allāh bin al-Ḥasan al-Lālakā'i, Sharh Ușūl I'tiqād Ahl alSunnah wa al-Jamā'ah min al-Kitāb wa al-Sunnah wa Ijmā' alSahāabah (Riyad : Dār al-Tayyibah, 1402H), 1: 72.

62 Al-Lālakā'i, Sharh Uṣūl I'tiqād Ahl al-Sunnah wa al-Jamā 'ah, 1: 5960; Jalāl al-Dīn al-Suyūțî, Miftāh al-Jannah fī al-Ihtijāj bi al-Sunnah (Madinah: al-Jāmi'ah al-Islāmiyyah, 1399), 64.

63 Ibid., 64; Shams al-Dīn al-Dhahabì, Siyar A 'lām al-Nubalā' (Beirut: Mu'assasah al-Risālah, 1413H), 7: 273. 
Al-Fuḍayl bin 'Iyāọ (w. 187H) turut menyebut mengenai golongan Ahl al-Sunnah wa al-Jamā'ah ketika membuat perbandingan dengan golongan Murji'ah dan Jahmiyyah. Beliau mengatakan, "Golongan Murji'ah berpendapat iman itu ialah perakuan dengan kata-kata tanpa amalan; Jahmiyyah pula berpendapat iman itu ialah makrifah tanpa perakuan dengan kata-kata dan amalan; manakala Ahl al-Sunnah pula mengatakan iman itu ialah makrifah, perakuan dengan kata-kata dan amalan." 64 Manakala Ahmad bin Hanbal (w. 241H) pula diriwayatkan pernah menegaskan bahawa, "Ini adalah mazhab ahli ilmu, așhāb al-äthār dan Ahl al-Sunnah yang berpegang teguh kepada al-Sunnah yang dikenali jejak langkahnya dan menjadi ikutan umat bermula daripada para sahabat Nabi SAW hingga ke hari ini." 65

Berdasarkan beberapa ungkapan golongan salaf berkenaan, dapat difahami bahawa istilah Ahl al-Sunnah wa al-Jamā'ah telah sedia digunakan sebelum kemunculan Abū al-Hasan al-Ash'arì dan Ashā'irah. Tanggapan Syiah Imāmiyyah Ithnā 'Ashariyyah bahawa Ahl al-Sunnah wa al-Jamā'ah itu hanya bermula dengan kemunculan Abū alHasan al-Ash'ari adalah tidak benar dan bertujuan menafikan keaslian mazhab tersebut yang berasal-usul daripada Rasulullah SAW dan para sahabat.

64 'Abd Allāh bin Aḥmad, al-Sunnah (Dammam: Dār Ibn al-Qayyim, 1406H), 1: 306; Muhd bin Jarì al-Ṭabari, Tahdhīb al-Āthār wa Tafșì al-Thābit 'an Rasūl Allāh min al-Akhbār (Kaherah: Mațba'ah alMadani, t.t), 2: 660; Hafiz bin Ahmad Hukmi, Ma'arij al-Qabūl bi Sharh Sullam al-Wuṣūl ilā 'Ilm al-Ușūl (Dammam: Dār Ibn alQayyim, 1990), 3: 1013.

65 Muhammad bin Abī Ya'lā, Tabaqāt al-Hanābilah (Beirut: Dār alMa'rifah, t.t), 1: 24; Hibbah Allāh Ibn 'Asākir, Tārīkh Madīnah Dimashq (Beirut: Dār al-Fikr, 1995), 32: 175. 
Mohd Aizam \& Mohd Fauzi, "Pemikiran Skeptikal Syiah terhadap Ahl alSunnah wa al-Jamā'ah," Afkār Vol. 21 Issue 1 (2019): 1-52

\section{iii. Ahl al-Sunnah wa al-Jamā'ah Sebagai Mazhab Akidah dan Fiqah}

Penyandaran istilah Ahl al-Sunnah wa al-Jamā'ah terhadap Abū al-Hasan al-Ash'ari ${ }^{66}$ bukan bermakna beliau merupakan pengasas Ahl al-Sunnah wa al-Jamā'ah, sebaliknya ia sebagai pengiktirafan terhadap sumbangan beliau dalam mempertahankan kesinambungan akidah Ahl al-Sunnah wa al-Jamā'ah sebagaimana yang dibawa oleh Rasulullah SAW, para sahabat dan salafussoleh daripada segala penyelewengan dan kesesatan. Demikian juga Abū Manșūr al-Māturidīi ${ }^{67}$ dan Māturídiyyah yang hampir

${ }^{66}$ Beliau adalah 'Alī bin Ismā‘ ‘il bin Isḥāq bin Sālim bin Ismā‘ ‘̄l bin 'Abd Allāh bin Mūsā bin Bilāl bin Abì Burdah bin Abī Mūsā al-Ash'arì. Dilahirkan di Kota Bașrah pada tahun 260H dan merupakan keturunan yang kesembilan daripada sahabat Nabi SAW iaitu Abū Mūsā alAsh'arí. Meninggal dunia di Baghdad pada tahun 324H. Beliau dikenali dengan pelbagai jolokan antaranya, Nāṣir al-Sunnah, 'Alam al-Dīn, Shaykh Taríqah Ahl al-Sunnah wa al-Jamā'ah dan Imām alMutakallimīn. Lihat Abū Bakr al-Khațīb al-Baghdādī, Tārīkh Baghdād (Beirut: Dār al-Kutub al-'Ilmiyyah, t.t), 11: 346; Ibn 'Asākir, Tabyīn Kadhib al-Muftarā fī mā Nusib Ilā Abì al-Hasan al-Ash 'arī (Beirut: Dār al-Kitāb al-'Arabī, 1404H), 34-34; 'Abd al-Raḥmān bin 'Alì bin al-Jawzì, al-Muntazam fī Tārīkh al-Mulūk wa al-Umam (Beirut: Dār șādir, 1358H), 14: 29; Hamad al-Sinān dan Fawzī al'Anjarī, Ahl al-Sunnah al-Ashā 'irah, Shahādah 'Ulamā' al-Ummah wa Adillatuhum (Kuwait: Dār al-Diyā', 1427H), 39.

${ }^{67}$ Beliau adalah Abū Manșūr Muḥammad bin Muḥammad bin Maḥmūd al-Māturīdi, al-Anșāīi, al-Ḥanafī, al-Samarqandì. Lahir pada tahun $238 \mathrm{H}$ dan wafat pada tahun $333 \mathrm{H}$ di Samarqand, salah sebuah kota yang terkenal di Asia Tengah. Beliau dikatakan berketurunan sahabat Nabi SAW, Abū Ayyūb Khālid bin Zayd bin Kulayb al-Anșārī. Sebagai penghormatan terhadap keilmuannya dalam bidang teologi dan sumbangannya dalam mempertahankan Ahl al-Sunnah wa alJamā'ah, beliau dikurniakan beberapa gelaran seperti 'Alam al-Hudā, Imām al-Hudā, Imām al-Mutakallimīn, Mușaḥhih 'Aqā'id alMuslimin, Ra'is Ahl al-Sunnah, Qudwah Ahl al-Sunnah wa al-Ihtidā', Rāfi ' A 'lām al-Sunnah wa al-Jamā 'ah dan Qāli 'Aḍ̄līl al-Fitnah wa al-Bid'ah. Lihat Murtậā al-Zabị̣ị, Tāj al-'Ārūs, 7: 456; Ismā'īil Bāshā al-Baghdādī, Hadiyyah al- 'Àrifīn Asmā' al-Mu'allifīn wa Āthār al-Mușannifīn (Beirut: Dār al-Kutub al-'Ilmiyyah, 1992), 6: 36; Muḥammad 'Amìm al-Iḥsān al-Barkatí, Qawā 'id al-Fiqh (Karachi: 
seiring dengan kemunculan Ashā'irah, turut membawa manhaj yang sama. Kedua-dua tokoh dan kumpulan ini kemudiannya telah menjadi pegangan majoriti umat Islam selepas mereka sehingga apabila disebut istilah Ahl alSunnah wa al-Jamā'ah secara mutlak, maka mereka yang dimaksudkan adalah golongan Ashā'irah dan Māturidiyyah. ${ }^{68}$

Menurut Tāj al-Dīn al-Subki, seluruh Ahl al-Sunnah wa al-Jamā'ah bersepakat bahawa iktikad mereka adalah satu walaupun berbeza dari sudut pendekatan dan disiplin yang disusun. Mereka boleh dirumuskan kepada tiga kelompok utama. Pertama, ahl al-hadith yang prinsip pegangan mereka adalah berteraskan dalil-dalil naqli iaitu al-Qur'an, al-Sunnah dan ijmak. Kedua, ahl al-nazar al'aqli wa al-șinā'ah al-fikriyyah yang terdiri daripada golongan Ashā'irah pimpinan Abū al-Hasan al-Ash'ari dan golongan Māturíidiyyah pimpinan Abū Manșūr al-Māturídí. Ketiga, ahl al-wujdān wa al-kashf yang terdiri daripada golongan sufi yang pada dasarnya turut berpegang kepada prinsip kumpulan pertama dan kedua. ${ }^{69}$

Al-Baghdādī ketika menjelaskan mengenai maksud hadis kumpulan yang selamat (al-firqah al-näjiyah) mengatakan mereka adalah kelompok Ahl al-Sunnah wa alJamā'ah. Ia terdiri daripada kedua-dua madrasah ahli alra'y dan ahl al-hadith sama ada daripada kalangan fuqaha', muhaddithīn, qurrā' dan mutakallimin yang bersepakat di atas prinsip akidah yang sama. Keimanan mereka tidak dicemari dengan pegangan ahli bid'ah seperti golongan Khawārij, Rāfiḍah, Qadariyyah dan keseluruhan pengikut hawa nafsu yang lain. Termasuk dalam kelompok ini adalah jumhur umat Islam yang mengikuti imam-imam

al-Ṣadaf Bablasharz, 1986), 197; Abū Manșūr al-Māturīi, Kitāb alTawhìd (taqdìm muhaqqiq) (Beirut: Dār Șādir, t.t.), 9.

68 Muḥammad Murtaḍā al-Husaynī al-Zabīī, Ittihāâf al-Sādah alMuttaqīn bi Sharh Ihyā' 'Ulūm al-Dīn (Beirut: Mu'assasah al-Tārīkh al-'Arabi, 1994), 2: 5.

${ }^{69}$ Ibid. 
mazhab fiqah seperti al-Shāfi‘‘ī, Mālik, Abū Ḥanífah, al' $\overline{\text { Uză }}$ 'i dan lain-lain. ${ }^{70}$

Walau bagaimanapun, mazhab Ahl al-Sunnah wa alJamā'ah menjadi semakin terkenal dengan kemunculan Abū al-Hasan al-Ash'ari yang digelar sebagai Shaykh alNazar dan imam dalam ilmu perbahasan dan tahqiq. Beliau berjaya mematahkan hujah-hujah golongan bid'ah seperti Qadariyyah, Najjāriyyah, Jahmiyyah, Jismiyyah, Rawāfiḍ dan Khawārij. Karya-karya beliau bertebaran ke serata tempat dan menjadi rujukan ramai ulama selepasnya. Di samping itu, beliau dikurniakan dengan pengikut yang ramai sehingga boleh dikatakan keseluruhan ahli hadis dan ahli al-ra'y yang tidak terpengaruh dengan $\mathrm{Mu}$ 'tazilah berada di atas mazhab beliau. ${ }^{71}$

\section{iv. Dakwaan Terhadap Kredibiliti Abū al-Ḥasan al- Ash'arí}

Mengenai dakwaan Khair Izzah bahawa Abū al-Hasan alAsh'ari tidak memiliki kredibiliti kerana hanya bertaubat daripada fahaman Mu'tazilah pada tahun 310 Hijrah ketika berumur 50 tahun, ia merupakan penyimpangan fakta yang jelas. Ini kerana, guru Mu'tazilah beliau, iaitu Abū 'Alì alJubbā', $\bar{i}$ dicatatkan dalam karya-karya sejarah meninggal dunia pada tahun 303 Hijrah. ${ }^{72}$ Sedangkan Abū al-Hasan alAsh'ari meninggalkan fahaman $\mathrm{Mu}^{\text {'tazilah sebelum }}$ kematian gurunya berdasarkan beberapa siri perdebatan yang pernah dinukilkan antara kedua-duanya. ${ }^{73}$ Ketika al-

70 'Abd al-Qāhir bin Țāhir al-Baghdādì, al-Farq Bayn al-Firaq (Beirut: Dār al-Āfāq al-Jadìdah, 1977), 19-20.

${ }^{71}$ Al-Baghdādī, Ușūl al-Dìn (Istanbul: Maṭba'ah al-Dawlah, 1928), 309310 .

72 Shams al-Dīn bin Ibn Khallikān, Wafiyyat al-A 'yān wa Anbā' Abnā', al-Zamān (Lubnān: Dār al-Thaqāfah, t.t), 4: 267; Abū al-Fạ̣l alHamadānī, Takmilah Tārìkh al-Ṭabarī (Beirut: Maṭba'ah alKāthūlikkiyyah, 1958), 17; Abū Muḥammad al-Yāfi'ī, Mir'āh al-Jinān wa 'Ibrah al-Yaqzān (Kaherah: Dār al-Kitāb al-Islāmí, 1993), 2: 241.

73 Antaranya, perdebatan yang melibatkan isu peletakan nama-nama Allāh SWT. Pada akhir perdebatan tersebut, al-Ash'ari menegaskan 
Jubbā'i meninggal dunia, Abū al-Ḥasan al-Ash 'ari berumur 43 tahun. Jika ditolak dengan umur baligh menurut pendapat jumhur ulama iaitu lima belas tahun ${ }^{74}$, bermakna beliau hanya berpegang dengan fahaman Mu'tazilah selama 28 tahun, bukan 40 tahun seperti yang dinukilkan dalam sesetengah riwayat.

Manakala baki umurnya selama 21 tahun dimanfaatkan untuk membantah golongan $\mathrm{Mu}$ 'tazilah dan ahli bid'ah yang lain. Ibn Fūrak mengatakan, karya-karya beliau yang membela Ahl al-Sunnah wa al-Jamā'ah mula tersebar selepas tahun 300 Hijrah sehingga ke tahun 324 Hijrah. ${ }^{75}$ Antaranya adalah karya beliau yang khusus dalam membantah akidah bekas gurunya, al-Jubbā' $\bar{i}$ setebal 40 juzuk. $^{76}$ Dalam kitab al-'Amd fí al-Ru'yah, beliau menyenaraikan beberapa judul karyanya. Topik yang dibahaskan amat luas, antaranya bantahan terhadap golongan Mulhidin (Ateisme), Mushabbihah, Mujassimah, Mu'tazilah, Qadariyyah, Syiah, Hinduisme, Yahudi, Nasrani dan Majusi, perbandingan firaq Islämiyyah dan lain-lain. ${ }^{77}$

Jumlah karya beliau dikatakan melebihi 300 buah. $^{78}$ Dengan apa yang telah dilakukan oleh beliau, ia termasuk

kepada al-Jubbā'`i bahawa manhaj beliau dalam peletakan nama Allah adalah berdasarkan keizinan syarak dan bukan menggunakan qiyās 'aqli. Ini menunjukkan sewaktu perdebatan ini berlaku, al-Ash'ari telah pun berpegang dengan manhaj Ahl al-Sunnah wa al-Jamā'ah. Lihat Tāj al-Dīn al-Subki, Țabaqāt al-Shāfi 'iyyah al-Kubrā (Kaherah: Hajr li al-Tibā'ah wa al-Nashr wa al-Tawzí‘, 1413H), 3: 358-359.

74 Wizārah al-Awqāf wa al-Shu'ūn al-Islāmiyyah-al-Kuwayt, alMawsū'ah al-Fiqhiyyah al-Kuwaytiyyah (Kuwait: Dār al-Salāsil, 1404H), 8: 192.

75 Ibn 'Asākir, Tabyīn Kadhib al-Muftarā, (Beirut: Dār al-Kitāb al'Arabi, 1404H), 127.

${ }^{76}$ Ibid., 128.

77 Ibid., 128-134.

${ }^{78}$ Ibid., 136. 
dalam kategori mereka yang telah menyatakan taubat, ${ }^{79}$ memperbaiki amalan dan menjelaskan kepada manusia dengan apa yang dipegang sebelumnya sebagaimana firman Allah SWT dalam surah al-Baqarah ayat 160:

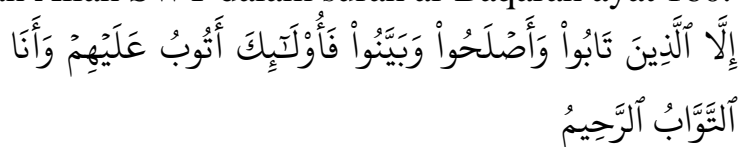

Terjemahan:

Kecuali orang-orang yang bertaubat, dan memperbaiki (amal buruk mereka) serta menerangkan (apa yang mereka sembunyikan); maka orang-orang itu, Aku terima taubat mereka, dan Akulah Yang Maha Penerima Taubat, lagi Maha Mengasihani.

Justeru, biarpun Abū al-Hasan al-Ash'arī pernah menganut fahaman $\mathrm{Mu}$ 'tazilah akibat terkesan dengan didikan al-Jubbā' $\bar{i}$, iaitu bapa tirinya semenjak kecil, namun beliau akhirnya kembali menganut pegangan Ahl alSunnah wa al-Jamā'ah. Menurut Ibn Fūrak, bapa kandung beliau iaitu Abū Bashr, Ismā‘ ‘il bin Isḥāq merupakan seorang ahli hadis berfahaman Ahl al-Sunnah wa alJamā'ah. Sebelum meninggal dunia, Abū Bashr telah mewasiatkan supaya al-Ash'ari menuntut dengan seorang imam hadis iaitu Zakariyyā bin Yahyā al-Sāji. ${ }^{80}$ Bermakna, pada peringkat awal, al-Ash'ari telah pun dididik dengan pegangan Ahl al-Sunnah wa al-Jamā'ah sehingga ibunya

79 Diriwayatkan bahawa Abū al-Ḥasan al-Ash'arī telah mengasingkan diri selama 15 hari, sebelum muncul dan mengisytiharkan diri bertaubat daripada pegangan Mu'tazilah. Beliau melakukan perisytiharan tersebut di atas mimbar Masjid Bașrah selepas menunaikan solat Jumaat dengan disaksikan oleh umat Islam. Lihat Ibn 'Asākir, Tabyīn, 39; al-Subkì, Țabaqāt, 3: 348.

${ }^{80}$ Ibid., 35; Zakariyyā bin Yahyā al-Sājìi, seorang imam hadis dan mufti penduduk Bașrah. Beliau terkenal dengan dua buah karya iaitu Ikhtilāf al- 'Ulamā' dan 'Ilal al-Hadith. Meninggal dunia pada tahun $307 \mathrm{H}$. Lihat al-Dhahabì, Siyar A 'lām al-Nubalā', 14: 198. 
berkahwin dengan al-Jubbā', $\bar{i}$, yang kemudian mengubah didikannya kepada $\mathrm{Mu}^{\text {'tazilah. }}{ }^{81}$

Walau bagaimanapun, setelah meninggalkan Mu'tazilah, beliau kembali melazimi al-Sāji. Menurut alDhahabi, al-Ash'ari menukilkan kata-kata salaf mengenai sifat Allah daripada al-Sāji dan mengikuti banyak pendapat al-Sāji dalam karya-karyanya. ${ }^{82}$ Selain itu, al-Ash'ari didapati banyak meriwayatkan hadis dalam tafsirnya daripada para ulama Ahl al-Sunnah wa al-Jamā'ah di Bașrah seperti 'Abd al-Rạ̣mān bin Khalaf al-Dabbi ${ }^{\overline{83}}$, Abū Khalifah al-Jamhị ${ }^{84}$ dan Muhammad bin Ya'qūb alMuqri'. ${ }^{85}$ Malah, salah seorang guru al-Ash'ari iaitu alDabbi meninggal dunia pada tahun 279 Hijrah ketika alAsh'ari berumur 19 tahun. Ia memberi petunjuk bahawa al-

81 'Abd al-Qādir bin Muhammad al-Qurashī, al-Jawāhir al-Mudidyyah fī Țabaqāt al-Hanafiyyah (Karachi: Mīr Muḥammad Khutub Khānah, t.t), 2: 247.

${ }^{82}$ Ibn 'Asākir, Tabyīn, 35; al-Dhahabī, Siyar A 'lām al-Nubalā', 14: 198.

${ }^{83}$ Beliau adalah 'Abd al-Raḥmān bin Khalaf bin al-Huṣayn al-Ḍabbì. Antara yang meriwayatkan hadis daripadanya ialah Abū Muhammad bin Șā'id, al-Qāẹi Abū Muḥammad al-Muhāmilì, Muḥammad bin Ja'far al-Mațîî dan Ismā'īl bin al-Ṣaffār. Meninggal dunia pada tahun 279H di Bașrah. Ibn 'Asākir menukilkan beliau sebagai salah seorang guru kepada al-Ash'arī. Lihat al-Baghdādī, Tārìkh Baghdād, 10: 275; Ibn 'Asākir, Tabyin, 400.

84 Beliau adalah al-Faḍl bin al-Hubab. Lahir pada tahun $206 \mathrm{H}$ dan meninggal dunia pada tahun $305 \mathrm{H}$. Al-Dhahabi menyifatkan beliau sebagai seorang muhaddith yang thiqah. Al-Dhahabi, al-Subki dan Ibn 'Asākir antara yang menukilkan bahawa al-Ash'ari telah berguru dengannya. Lihat al-Dhahabi, Siyar A 'lām al-Nubalā', 14: 8, 15: 86; Tāj al-Dīn al-Subki, Tabaqāt al-Shāfi 'yyah al-Kubrā (Kaherah: Hajr li al-Ṭibā'ah wa al-Nashr wa al-Tawzi'‘, 1413H), 3: 355; Ibn 'Asākir, Tabyin, 400.

${ }^{85}$ Beliau adalah Abū al-'Abbās Muhammad bin Ya'qūb bin al-Hajjāj alTaymi al-Bașrí al-Muqri’. Meninggal dunia di Bașrah selepas tahun 330H. Al-Subki dan Ibn 'Asākir menukilkan beliau sebagai salah seorang guru al-Ash'ari. Lihat Muḥammad bin Ahmad al-Dhahabi, Ma 'rifah al-Qurrā' al-Kibār 'alā al-Tabaqāt wa al-A 'șār (Beirut: Mu'assasah al-Risālah, 1404H), 1: 286; al-Subkī, Tabaqāt, 3: 355; Ibn 'Asākir, Tabyīn, 400. 
Ash'ari tetap melazimi para ulama Ahl al-Sunnah wa alJamā'ah walaupun ketika beliau masih menganut fahaman $\mathrm{Mu}$ 'tazilah. Ia akhirnya mendorong beliau untuk kembali semula kepada pegangan Ahl al-Sunnah wa al-Jamā'ah.

\section{v. Dakwaan Ahl al-Sunnah wa al-Jamā'ah Sebuah Pakatan Yang Rapuh: Perbandingan Dengan Syiah}

Mengenai dakwaan Faisal Tehrani bahawa mazhabmazhab akidah dan fiqah yang terdapat dalam Ahl alSunnah wa al-Jamā'ah merupakan sebuah pakatan yang rapuh, ini adalah kesalahfahaman beliau dalam menilai Ahl al-Sunnah wa al-Jamā'ah sebagai sebuah aliran yang merangkumi disiplin akidah dan fiqah. Istilah pakatan yang digunakan oleh Faisal Tehrani tidak wajar disandarkan kepada mazhab-mazhab di bawah Ahl al-Sunnah wa alJamā'ah. Tidak pernah dicatatkan dalam mana-mana karya bahawa terdapat mazhab-mazhab tertentu yang berpakat lalu bergabung membentuk satu pakatan yang dinamakan dengan Ahl al-Sunnah wa al-Jamā'ah. Sebaliknya, sebagaimana yang dijelaskan sebelum ini, Ahl al-Sunnah wa al-Jamā'ah merupakan istilah yang bersumberkan dalil syarak yang telah pun digunapakai sejak zaman para sahabat, jauh sebelum kemunculan mazhab-mazhab tersebut.

Dari sudut akidah, seluruh Ahl al-Sunnah wa alJamā'ah bersepakat bahawa iktikad mereka adalah satu walaupun berbeza dari sudut pendekatan dan disiplin yang disusun. ${ }^{86}$ Sekalipun wujud perselisihan pendapat antara Ashā'irah dan Māturidiyyah dalam permasalahan tertentu, ia hanya dalam perkara furu' yang tidak membawa kepada kafir mengkafir atau bid'ah membid'ah antara satu sama lain. ${ }^{87}$ Demikian jua perbezaan pendapat yang terjadi antara

${ }^{86}$ Al-Zabìi, Ittihāf al-Sādah, 2: 5.

${ }^{87}$ Al-Subkì, Ṭabaqāt, 3: 378; Ibn 'Asākir, Tabyīn, 409; 'Alī bin Sulțān al-Qārì, Mirqāt al-Mafātīh Sharh Mishkāt al-Mașābīh (Beirut: Dār alKutub al-'Ilmiyyah, 2001), 1: 383. 
mazhab-mazhab fiqah, ia berlaku atas dasar ijtihad dalam perkara yang dibenarkan oleh syarak. Kerana itu, mazhabmazhab fiqah Ahl al-Sunah wa al-Jamā'ah bukan sekadar terbatas kepada empat, bahkan meliputi semua mazhab para sahabat dan tabi ${ }^{\circ}$ in. ${ }^{88}$ Dengan kata lain, perselisihan pendapat dalam persoalan fiqah merupakan perkara yang lazim berlaku sama ada antara mazhab atau dalam sesebuah mazhab yang sama.

Hal ini turut berlaku dalam aliran Syiah. Lebih kritikal apabila berlaku perselisihan pendapat dalam perkara $u s ̦ \bar{u} l$ sehingga menyebabkan Syiah terpecah kepada lima kumpulan besar iaitu Syiah Ghulāh, Syiah Zaydiyyah, Syiah Kaysāniyyah, Syiah Imāmiyyah dan Syiah Ismā'īliyyah. Syiah Ghulāh terpecah pula kepada dua puluh empat kumpulan, Kaysāniyyah kepada enam kumpulan, Zaydiyyah kepada sembilan kumpulan, Imāmiyyah kepada tiga puluh sembilan kumpulan dan Ismā'iiliyyah terpecah kepada lapan kumpulan. ${ }^{89}$ Ithnā 'Ashariyyah termasuk dalam kalangan Syiah Imāmiyyah. Mereka menganggap golongan selain daripada mereka sebagai kafir. Ketika membicarakan isu kenajisan golongan yang menyalahi Syiah Imāmiyyah Ithnā 'Ashariyyah, al-Khaw' $\bar{i}$ mengatakan golongan yang menyalahi mereka diakui keislamannya secara zahir, walaupun mereka pada hakikatnya adalah kafir di akhirat kelak. ${ }^{90}$

Dalam masa yang sama, Syiah Imāmiyyah Ithnā 'Ashariyyah sendiri berpecah kepada dua aliran utama iaitu Ikhbāriyyah dan Ușūliyyah. Kumpulan Ikhbāriyyah

${ }^{88}$ Abū Ishạa al-Shīrāzí, Ṭabāqāt al-Fuqahā' (Beirut: Dār al-Rā'id al'Arabi, 1970).

89 Nāṣir al-Dīn al-Hindi, al-Suyūf al-Mushriqah wa Mukhtașar alȘawā'iq al-Muhriqah (Kaherah: Maktabah al-Imām al-Bukhārī, 2008), 59.

${ }^{90}$ Al-Mirzā 'Alī al-Ghurawi al-Tabrizìi, al-Tanqīh fī Sharḥ al- 'Urwah alWuthqā Taqrīran li Bahth Āyah Allāh al-'Uzmā al-Sayyid Abū alQāsim al-Mūsawì al-Khaw'ì (Qom: al-Hādi li al-Maṭbū'āt, 1410H), 3: 87. 
mengharamkan ijtihad ke atas faqih kerana ia tidak maksum. Namun demikian, realiti semasa menyedarkan sebahagian mereka akan kepincangan pegangan tersebut lalu mengambil pendirian mengharuskan ijtihad. Kelompok ini dikenali sebagai beraliran Ușūliyyah. Keduadua aliran ini menyaksikan pertentangan yang sengit sehingga ke peringkat kafir mengkafir dan menghalalkan darah antara satu sama lain..$^{91}$ Menurut al-Ṭabātabā' $\bar{i}$, istilah al-Ikhbārī dan al-Ușūli telah menggugat kesatuan kelompok Syiah. Ia menyumbang kepada perpecahan, perlecehan dan cacian antara satu sama lain. ${ }^{22}$

Kedua-dua pihak saling bantah membantah sehingga ke peringkat kafir mengkafir bahkan sebahagian mereka berfatwa mengharamkan solat di belakang kelompok yang tidak sealiran dengannya. ${ }^{93}$ Terdapat juga kalangan para ulama Ikhbāriyyah yang tidak menyentuh karya-karya ulama Ușūliyyah kecuali dengan berlapik, kerana menganggap kenajisannya. ${ }^{94}$ Menurut al-Mallāḥ, Ithnā 'Ashariyyah terbahagi kepada Ușūliyyah, Ikhbāriyyah, Shaykhiyyah, Kashfiyyah, Rukniyyah, Karimkhāniyyah dan Qazlabāshiyyah, semuanya termasuk dalam kelompok Ithnā 'Ashariyyah, namun mereka saling kafir mengkafir satu sama lain. ${ }^{95}$

Dalam pada itu, berlaku pula khilaf dalam kalangan golongan Ușūliyyah berkenaan isu Wilāyah al-Faqīh. Sebahagian mengatakan, Wilāyah al-Faqīh harus

91 Muḥammad Ḥasan Āl al-Ṭāliqānī, al-Shaykhiyyah, Nash'atuha wa Tațawwaruha wa Maṣādir Dirāsatiha (Baghdad: Dār al-Kitāb al'Arabì, 2007), 38-42.

92 Muhammad Sa'īd al-Hakīm al-Ṭabāṭabā'i, al-Ușūliyyah wa alIkhbāriyyah: Bayn al-Asmā' wa al-Wāqi ' (Najaf: Dār al-Hilāl, 2005), 12.

93 Muḥammad Jawwād Mughniyah, Ma' 'Ulamā' al-Najaf al-Ashraf (Beirut: Dār al-Jawwād, 1992), 74.

94 Àl al-Ṭāliqāni, al-Shaykhiyyah, 39.

${ }^{95}$ Maḥmūd al-Mallāh, al-Ārā' al-Ṣarīhah li Binā' Qawmiyyah Ṣaḥihhah (Baghdad: Maṭba'ah Dār al-Salām, 1956), 81. 
diserahkan kepada individu yang tidak maksum iaitu seorang faqih. Ia akan bertindak sebagaimana kuasa yang ada pada seorang imam maksum. Sebahagian pula mengatakan, Wilāyah al-Faqīh tidak boleh diserahkan kepada seorang yang tidak maksum walaupun ia seorang faqīh. Bagi yang mendukung Wilāyah al-Faqīh, mereka mengeluarkan fatwa murtad terhadap golongan yang menentang konsep tersebut. Pada tahun 2010, kepimpinan tertinggi Iran, 'Ali Khāmana'i telah mengisytiharkan secara terbuka bahawa dirinya merupakan pengganti (sementara) Imam al-Mahdi dan Rasulullah SAW, dan mentaatinya adalah wajib. ${ }^{96}$

Beberapa orang tokoh ulama dan pemimpin Iran yang mendukung kuat Wilāyah al-Faqīh seperti Muhammad Taqi Miṣbāḥ Yazdīī, Maḥmūd Nabwiyān, Ghulām Husayn Ghìb Barūr dan 'Abd Allāh Hạji Șādiqi menyifatkan penentang Wilāyah al-Faqīh sebagai terkeluar daripada Islam, syirik kepada Allah bahkan setaraf dengan pembunuh Husayn. ${ }^{98}$ Perpecahan yang melibatkan semua peringkat aliran Syiah ini menunjukkan ia bukan sebuah mazhab yang berdiri di atas asas atau sumber yang sama. Biarpun kesemua cabang aliran tersebut mendakwa berpegang kepada Ahl al-Bayt, namun hakikatnya ia sekadar dakwaan semata-mata. Sebaliknya majoriti aliran tersebut muncul akibat kefanatikan kepada tokoh masingmasing sehingga membelakangkan sumber agama yang asli iaitu al-Qur'an dan al-Sunnah.

96 'Khāmana'ì: Anā nā'ib al-Mahdi al-Muntaẓar wa țā'atì wajibah 'ala al-jami'”, Al Arabiya, dicapai 14 November 2017, https://www.alarabiya.net/articles/2010/07/22/114511.html.

97 “Al-abb al-rūḥi li Aḥmadi Nijād: Man lam yaqbal bi ḥukm Wilāyah al-Faqih yu'add murtadan", Al Arabiya, dicapai 14 November 2017, https://www.alarabiya.net/articles/2010/06/14/111324.html.

98 "Ustādh fï Hawzah Qom, ghair al-mu'min bi Wilāyah al-Faqih murtadd", Șuhf.net, dicapai 14 November 2017, https://www.suhf.net/world/315998/أستاذ-في-حوزة-قم-غير -المؤمن-بولاية-الفقيه 
Mohd Aizam \& Mohd Fauzi, "Pemikiran Skeptikal Syiah terhadap Ahl alSunnah wa al-Jamā'ah," Afkār Vol. 21 Issue 1 (2019): 1-52

\section{vi. Dakwaan Ahl al-Sunnah wa al-Jamā'ah Terputus Daripada Sahabat}

Syiah Imāmiyyah Ithnā 'Ashariyyah cuba menutup perpecahan mereka sendiri dengan memperbesar-besarkan perbezaan pendapat yang wujud dalam Ahl al-Sunnah wa al-Jamā'ah. Ia dilakukan dengan tanggapan mazhab Ahl alSunnah wa al-Jamā'ah itu tidak asli, mazhab baharu dan terputus daripada Rasulullah SAW dan para sahabat. Pandangan Syiah Imāmiyyah Ithnā 'Ashariyyah ini bertentangan dengan susur galur keilmuan yang diperoleh oleh para imam mazhab empat sebagaimana yang diiktikadkan oleh Ahl al-Sunnah wa al-Jamā'ah.

Ini kerana, sedia dimaklumi bahawa keempat-empat imam tersebut mengambil ilmu daripada silsilah yang bersambung sehingga kepada para sahabat Rasulullah SAW. Al-Imām Abū Ḥanifah mengambil kebanyakan ilmu dan fiqahnya daripada guru tersohor beliau iaitu Hammād bin Abi Sulaymān. Hammād pula merupakan murid kepada Ibrāhìm al-Nakha' $\bar{i}$ al-Sha'bìi, manakala kedua-duanya pula mengambil ilmu daripada Shurayh al-Qāḍi, 'Alqamah bin Qays, Masrūq al-Ajda' dan lain-lain yang merupakan murid kepada dua orang tokoh sahabat tersohor iaitu 'Ali bin Abi Ṭālib dan 'Abd Allāh bin Mas'ūd. ${ }^{99}$

Al-Imām Mālik terkenal mengambil ilmunya daripada penduduk Madinah. Manakala penduduk Madinah pula memperoleh ilmu daripada para ahli fiqah yang tujuh. ${ }^{100}$ Sedangkan mereka adalah murid kepada para sahabat Rasulullah SAW seperti Zayd bin Thābit dan 'Abd Allāh bin 'Umar. ${ }^{101}$ Al-Imam al-Shāfi'‘ pula membentuk

\footnotetext{
99 Abū Zahrah, Muhammad, Tārīkh al-Madhāhib al-Islāmiyyah (Kaherah: Dār al-Fikr al-'Arabi,t.t), 335.

${ }^{100}$ Mereka adalah Sa'id bin al-Musayyib, 'Urwah bin Zubayr, Khārijah bin Zayd, al-Qāsim bin Muḥammad, Abū Bakr bin 'Abd al-Raḥmān, Sulaymān bin Yasār dan 'Ubayd Allāh bin 'Abd Allāh bin 'Utbah bin Mas'ūd. Lihat Ibn al-Qayyim, I'lām al-Muwaqqi'in 'an Rabb al'Ālamin, 1: 23.

101 Abū Zahrah, Tārīkh al-Madhāhib al-Islāmiyyah, 373.
} 
keilmuannya menerusi penduduk Makkah yang mewarisi ilmu daripada 'Abd Allāh bin 'Abbās, kemudian beliau turut mengambil ilmu daripada al-Imām Mālik. ${ }^{102}$ Demikian juga al-Imām Aḥmad bin Hanbal yang mengikuti mazhab Ahli Hadith. Beliau mengambilnya daripada Sufyān bin 'Uyaynah dan 'Amru bin Dỉnar daripada Ibn 'Abbās dan Ibn 'Umar serta selain mereka. ${ }^{103}$

Selain itu, terdapat ulama Syiah Imāmiyyah Ithnā 'Ashariyyah mengakui kebersambungan ilmu keempatempat imam tersebut dengan para sahabat termasuk 'Ali bin Abi Țālib sendiri. Al-Hilli mengatakan, Abū Hanifah merupakan murid Ja'far al-Ṣādiq, al-Șādiq pula murid kepada al-Bāqir, al-Bāqir murid kepada Zayn al-'Ābidīn, Zayn al-'Ābidin menuntut dengan al- Husayn dan alHusayn menuntut dengan bapanya, 'Alì bin Abi Tālib. Mālik pula murid kepada Rabi'ah al-Ra'y, Rabi' ah murid kepada 'Ikrimah, 'Ikrimah murid kepada Ibn 'Abbās dan Ibn 'Abbās murid kepada 'Alì. Al-Shāfi' $\bar{i}$ juga sama kerana menuntut dengan murid Abū Hanifah iaitu Muḥammad bin al-Ḥasan. Demikian jua Aḥmad bin Hanbal yang menuntut dengan al-Shāfi' $\bar{i}$, maka fiqah kedua-duanya kembali kepada 'Ali. ${ }^{104}$

Demikian juga akidah Ashā'irah yang digagaskan oleh al-Imām Abū al-Hasan al-Ash'ari dan dianut oleh majoriti penganut Ahl al-Sunnah wa al-Jamā'ah di dunia, ia bukan suatu mazhab baharu yang terputus daripada Rasulullah SAW dan para sahabat seperti yang dinyatakan oleh Faisal Tehrani. Sebaliknya, mazhab yang dipegang oleh al-Imām Abū al-Hasan al-Ash'ari adalah berpandukan nas-nas alQur'an dan al-Sunnah sebagaimana yang difahami oleh salafussoleh. Al-Imām Tāj al-Dīn al-Subkì mengatakan

\footnotetext{
102 Ibid., 411.

103 Ibid., 456.

104 Ibn Muțahhar al-Hilli, Kashf al-Yaqīn fï Fadā'il Amìr al-Mu'minīn 'alayh al-salām (Tehran: Wizārah al-Irshād, 1411H), 58; Al-Muzaffar al-Najafí, Dalā'il al-Șidq, 6: 331.
} 
ketika menjawab persoalan mengenai gelaran al-Ash'ari terhadap para penganut mazhabnya:

"Ketahuilah bahawa Abū al-Hasan tidak
mereka-reka pendapat dan mengasaskan
mazhab (baharu), akan tetapi beliau
memperakui mazhab salaf dan
memperjuangkan apa yang dipegang oleh para
sahabat r.a.h. Penyandaran (gelaran)
kepadanya, berdasarkan (usaha) beliau
meletakkan jalan salaf sebagai suatu landasan,
berpegang (kukuh) dengannya dan menegakkan
hujah dan bukti ke atasnya. Ini menjadikan
orang yang mengikutinya pada hal tersebut dan
melalui jalannya dalam mengambil dalil-dalil
digelar sebagai Ash'ari”, ${ }^{105}$

\section{Rumusan}

Berdasarkan perbahasan di atas, dapat disimpulkan karyakarya Syiah Melayu tersebut gagal untuk membuktikan dakwaan-dakwaan skeptikal mereka terhadap mazhab Ahl al-Sunnah wa al-Jamā'ah. Bahkan terbukti bahawa Ahl alSunnah wa al-Jamā'ah merupakan sebuah mazhab yang tertegak di atas susur galur keilmuan yang bersambung kepada para sahabat, seterusnya kepada junjungan besar Rasulullah SAW. Ia bukan sebuah mazhab baharu yang wujud pada zaman terkemudian hasil daripada krisis politik antara 'Ali dan $\mathrm{Mu}$ 'āwiyah atau muncul berasaskan retorika menentang fahaman $\mathrm{Mu}$ 'tazilah yang berleluasa pada era 'Abbāsiyyah.

Sebaliknya, Ahl al-Sunnah wa al-Jamā'ah tidak lain merupakan ajaran asal yang diwariskan oleh Rasulullah SAW kepada umat ini. Ia menjadi pembeza antara dua golongan umat Islam. Segolongan yang masih kekal di atas manhaj Baginda SAW, digelarkan dengan pengikut alSunnah dan al-Jamā'ah. Sementara segolongan lagi yang

105 Al-Subkī, Ṭabaqāt al-Shāfi yyah al-Kubrā, 3: 365. 
tersasar daripada manhaj Baginda SAW seperti Syiah, Khawārij, Murji'ah, Qadariyyah, Jabariyyah, Mujassimah, Mulhidah dan lain-lain.

\section{Rujukan}

Abì Ya 'lā, Muhammad. Tabaqāt al-Hanābilah. Beirut: Dār al-Ma'rifah, t.t.

Abū Zahrah, Muhammad. Tārīkh al-Madhāhib alIslāmiyyah. Kaherah: Dār al-Fikr al-'Arabi, t.t.

Al-Ājurrí, Muhammad bin al-Husayn. Al-Sharì 'ah. Riyāḍ: Dār al-Wațan, 1999.

Āl al-Kāshif al-Ghițā', Muhammad al-Husayn. Aṣl alShì'ah wa Ușūluhā: Muqāranah ma' al-Madhāhib alArba 'ah. Beirut: Dār al-Aḍwā', 1990.

Āl al-Ṭāliqānì, Muhammad Ḥasan. Al-Shaykhiyyah, Nash'atuhā wa Tațawwaruhā wa Mașādir Dirāsatihā. Baghdad: Dār al-Kitāb al-'Arabì, 2007.

Āli 'Ușfūr, Husayn bin Muḥammad. Al-Mahāsin alNafsāniyyah fì Ajwibah al-Masā'il al-Khurasāniyyah. Beirut: Dār al-Mashriq al-'Arabī al-Kabīir, 1979.

Amin, Ahmad. Fajr al-Islām. Kaherah: Maktabah alNahḍah, 1965.

Anas, Mālik. Al-Muwațța'. Mesir: Dār Iḥyā' al-Turāth al'Arabi, t.t.

Al-'Awwād, Badr bin Nāșir. Al-Naṣb wa al-Nawāṣib. Riyaụ: Maktabah Dār al-Minhāj, 1433H.

'Awwāji, Ghalib bin 'Ali. Firaq Mu'àsirat Tantasib Ilā alIslām wa Bayān Mawqif al-Islām minhā. Jeddah : alMaktabah al-'Așriyyah al-Dhahabiyyah, 2001.

Al-Baghdādī, 'Abd al-Qāhir bin Țāhir. Al-Farq Bayn alFiraq. Beirut: Dār al-Āfāq al-Jadīdah, 1977.

Al-Baghdādī, 'Abd al-Qāhir bin Ṭāhir. Ușūl al-Dīn. Istanbul: Matba'ah al-Dawlah, 1928.

Al-Baghdādī, Abū Bakr al-Khațīb. al-Faqīh wa alMutafaqqih. Saudi: Dār Ibn al-Jawzì, 1421H. Al-Baghdādī, Abū Bakr al-Khațīb. Tārìkh Baghdād. Beirut:

Dār al-Kutub al-'Ilmiyyah, t.t. 
Al-Baghdādī, Ismā'īl Bāshā. Hadiyyah al - 'Ārifīn Asmā' alMu'allifīn wa Āthār al-Muṣannifīn. Beirut: Dār al-Kutub al-'Ilmiyyah, 1992.

Al-Bahrānī, Hāshim bin Sulaymān. Hilyah al-Abrār fī Ahwāl Muhammad wa Älih al-Ațārr. Qom: Mu'assasah al-Ma'ārif al-Islāmiyyah, 1411H.

Al-Barkatí, Muḥammad 'Amīm al-Iḥsān. Qawā 'id al-Fiqh. Karachi: al-Șadaf Bablasharz, 1986.

Al-Bayhaqī, Abū Bakr. Sunan al-Bayhaqī al-Kubrā. Makkah al-Mukarramah: Maktabah Dār al-Bāz, 1994.

Al-Bukhārī, Muḥammad bin Ismā'il. Al-Jāmi ' al-Ṣahịh alMukhtașar. Beirut: Dār Ibn Kathìr, 1987.

Al-Dhahabī, Shams al-Dīn. Ma 'rifah al-Qurrā' al-Kibār 'alā al-Tabaqāt wa al-A 'șār. Beirut: Mu'assasah alRisālah, 1404H.

Al-Dhahabì, Shams al-Dīn. Siyar A 'lām al-Nubalā' . Beirut: Mu'assasah al-Risālah, $1413 \mathrm{H}$.

Faisal Tehrani. Perempuan Nan Bercinta. Kuala Lumpur: ITBM, 2012.

Al-Hajjāj, Muslim. Șaḥihh Muslim. Beirut: Dār Ihyeā’ alTurāth al-'Arabī, t.t.

Al-Hamadānī, Abū al-Faḍl. Takmilah Tārīkh al-Tabarī. Beirut: Maṭa'ah al-Kāthūlìkiyyah, 1958.

Al-Hillì, al-Ḥasan bin 'Alí. Al-Rijāl. Najaf: Manshūrāt alMațba'ah al-Haydariyyah, 1972.

Al-Hilli, Ibn al-Muțahhar. Kashf al-Yaqīn fī Fadā'il Amīr al-Mu'minìn 'alayh al-salām. Tehran: Wizārah alIrshād, $1411 \mathrm{H}$.

Al-Hindī, Nāṣir al-Dīn. Al-Suyūf al-Mushriqah wa Mukhtașar al-Șawā 'iq al-Muhriqah. Kaherah: Maktabah al-Imām al-Bukhārī, 2008.

Hukmí, Hafiz bin Aḥmad. Ma'arij al-Qabūl bi Sharh Sullam al-Wuṣūl ilā 'Ilm al-Uṣūl. Dammam: Dār Ibn alQayyim, 1990. 
Al-Ḥurr al-'Āmili, Muhammad bin Hasan. Tafṣil Wasā'il al-Shì'ah ilā Tahṣil Masā'il al-Shari'ah. Qom: Mu'assasah Ahl al-Bayt li Ihyā al-Turāth, 1409H.

Ibn 'Abd al-Barr, Yūsuf bin 'Abd Allāh. Al-Tamhìd fī alMuwatta' min al-Ma 'ānì wa al-Asānìd. Maghrib: Wizārah 'Umūm al-Awqāf wa al-Shu'ūn al-Islāmiyyah, $1387 \mathrm{H}$.

Ibn 'Asākir, 'Alì bin al-Ḥasan. Tabyīn Kadhib al-Muftarā fī mā Nusib Ilà Abì al-Hasan al-Ash 'arì. Beirut: Dār alKitāb al-'Arabi, 1404H.

Ibn 'Asākir, 'Alī bin al-Ḥasan. Tārīkh Madīnah Dimashq. Beirut: Dār al-Fikr, 1995.

Ibn 'Ațiyyah, Maqātil. Abhā al-Murād fī Sharh Mu'tamar 'Ulamā' Baghdād. Beirut: Mu'assasah al-A'lami, $1423 \mathrm{H}$.

Ibn Aḥmad, 'Abd Allāh. Al-Sunnah. Dammam: Dār Ibn alQayyim, $1406 \mathrm{H}$.

Ibn al-Jawzī. Al-Muntazam fī Tārīkh al-Mulūk wa alUmam. Beirut: Dār Șādir, 1358H.

Ibn al-Qayyim al-Jawziyyah. I'làm al-Muwaqqi'in 'an Rabb al-'Ālamin. Beirut: Dār al-Jīil, 1973.

Ibn Bābawayh, 'Alì bin al-Husayn. Man lā Yahduruh alFaqīh. Qom: Mu'assasah al-Nashr al-Islāmì, 1413H. Ibn Hajar al-'Asqalānì. Ahmmad bin 'Alì. Fatḥ al-Bāri Sharh Sahịh al-Bukhārì. Beirut: Dār Ma'rifah, t.t.

Ibn Hanbal, Aḥmad bin Muhammad. Musnad al-Imām Ahmad. Kaherah: Mu'assasah Qarțabah, 2011.

Ibn Hazm, Abū Muhammad. Al-Fișal fì al-Milal wa alAhwā' wa al-Nihal. Kaherah: Maktabah al-Khānji, t.t. Ibn Hịbān, Muḥammad. Sạhịh ibn Hibbān bi Tartīb Ibn Balbān. Beirut: Mu'assasah al-Risālah, 1993.

Ibn Khallikān, Shams al-Dīn. Wafiyyat al-A 'yān wa Anbā' Abnā' al-Zamān. Lubnān: Dār al-Thaqāfah, t.t.

Ibn Mājah, Muḥammad bin Yazìd. Sunan Ibn Mājah.

Beirut: Dār al-Fikr, t.t. 
Al-Irbilī, 'Alī bin 'Īsā. Kashf al-Ghummah. Beirut: Dār alAḍwā', 1985.

Al-Jazā'irī, Ni‘mah Allāh. Al-Anwār al-Nu'māniyyah.

Beirut: Dār al-Qāri', 2008.

Al-Jurjānī, Hạzah bin Yūsuf. Tārīkh Jurjān. Beirut: Ālam al-Kutub, 1981.

Al-Kāshānī, Muhammad bin Murtaḍā. Al-Wāfī. Asfahān: Maktabah al-Imām Amīr al-Mu'minīn 'Alì 'alayh alsalām, $1406 \mathrm{H}$.

Khair Izzah. Meniti Titian Kebenaran. t.t.p.: Al-Muntazar Resources, 2011.

Al-Khājū'i, Muhammad bin Ismā'īl. Al-Rasā'il alFiqhiyyah. Qom: Dār al-Kutub al-Islāmí, 1411H.

Al-Kulayni, Muhammad bin Ya'qūb. Al-Kāfī. Qom: Dār alHadith, 1429H.

Al-Lālakā'i, Hibah Allāh bin al-Ḥasan. Sharh Ușūl I'tiqād Ahl al-Sunnah wa al-Jamā'ah min al-Kitāb wa alSunnah wa Ijmā' al-Ṣahābah. Riyad : Dār al-Tayyibah, $1402 \mathrm{H}$.

Al-Majlisī, Muhammad Bāqir. Biḥ̄ar al-Anwār al-Jāmi 'ah lidurar Akhbār al-A'immah al-Ațhār. Beirut: Dār Ihyā' al-Turāth al-'Arabi, $1403 \mathrm{H}$.

Al-Mallāḥ, Maḥmūd. Al-Ārā' al-Ṣarịhah li Binā' Qawmiyyah Ṣahīhah. Baghdad: Maṭba'ah Dār al-Salām, 1956.

Al-Mar'ashī, Qāḍi Nūr Allāh. Ihqāa al-Haq wa Izhāq alBātill. Qom: Maktabah Āyat Allāh al-Mar'ashī al-Najafī, 1409H.

Al-Mu'allim, Muḥsin. Al-Naṣb wa al-Nawāṣib. Beirut: Dār al-Hudā, 1997.

Al-Mufīd, Muhammad bin Muhammad. Al-I'tiqāāāt. Qom: al-Mu'tamar al-'Alamì li Alfiyah al-Shaykh al-Ṣadūq, $1413 \mathrm{H}$.

Mughniyah, Muḥammad Jawwād. Ma' 'Ulamā' al-Najaf al-Ashraf. Beirut: Dār al-Jawwād, 1992. 
Muḥammad bin 'Alì bin Bābawayh. Thawāb al-A'māl wa 'Iqāb al-A 'māl. Qom: Dār al-Sharíf al-Riḍā, 1406H.

Muhsin, 'Alì Āli. Li Allāh wa li al-Haqíqah. Tehran: Mash'ar, $1382 \mathrm{H}$.

Al-Musawì, Mūsā. al-Shì'ah wa al-Taṣhịh: al-Ṣirā' bayn al-Shī'ah wa al-Tashayyu'. 'Ammān: Dār 'Ammār, 1998.

Al-Māturīīi, Abū Manșūr. Kitāb al-Tawhìd. Beirut: Dār Șādir, t.t.

Al-Najafī, Muhammad Ḥasan al-Muẓaffar. Dalā'il al-Ṣidq li Nahj al-Haq. Qom: Mu'assasah Āl al-Bayt, 1422H.

Al-Nawbakhtí, al-Ḥasan bin Mūsā. Firaq al-Shì'ah. Istanbul: Maṭa'ah al-Dawlah, 1931.

Al-Qārì, 'Alī bin Sulțān. Mirqāt al-Mafātīh Sharh Mishkāt al-Mașābihh. Beirut: Dār al-Kutub al-'Ilmiyyah, 2001.

Al-Qummì, Sa'd bin 'Abd Allāh. al-Maqālāt wa al-Firaq. Tehran: Maṭba'ah Haydari, 1963.

Al-Qurashi, 'Abd al-Qādir bin Muḥammad. Al-Jawāhir alMudiyyah fī Tabaqāt al-Hanafiyyah. Karachi: Mir Muhammad Khutub Khānah, t.t.

Al-Sakhāwī, Abū al-Khayr. Al-Maqāṣid al-Hasanah fī Bayān Kathīr min al-Ahādìth al-Mushtaharah 'alā alAlsinah. Beirut: Dār al-Kitāb al-'Arabì, 1405H.

Al-Sam'āni, Manșūr bin Muḥammad. Qawāṭi ' al-Adillah fī al-Ușūl. Beirut: Dar al-Kutub al-'Ilmiyyah, 1997.

Seksyen Akidah, JAKIM. "Kertas Makluman Perkembangan Terkini Isu Syiah di Malaysia," 2013.

Al-Shahrastānī, Muhammad bin 'Abd al-Karīm. Al-Milal wa al-Nihal. Beirut: Dār al-Ma'rifah, 1404H.

Al-Shāțibìi, Abū Isḥāq. Al-I'tiṣām. Mesir: al-Maktabah alTijāriyyah al-Kubrā, t.t.

Al-Shāṭibì, Abū Ishāâ. Al-Luma' fì Ușūl al-Fiqh. Beirut: Dār al-Kutub al-'Ilmiyyah, 1985.

Al-Shāțibìi, Abū Isḥāq. Tabāqāat al-Fuqahā' . Beirut: Dār alRā'id al-'Arabì, 1970. 
Shibr, 'Abd Allāh. Haq al-Yaqīn fī Ma 'rifah Ușūl al-Dīn. Qom: Anwār al-Hudā, 1424H.

Al-Sinān, Hamad \& al-'Anjarī, Fawzì. Ahl al-Sunnah alAshā 'irah, Shahādah 'Ulamā' al-Ummah wa Adillatuhum. Kuwait: Dār al-Diyā', 1427H.

Al-Subkī, Tāj al-Dīn. Tabaqāt al-Shāfi iyyah al-Kubrā. Kaherah: Hajr li al-Ṭibā'ah wa al-Nashr wa al-Tawzi' $1413 \mathrm{H}$.

Al-Suyūțí, Jalāl al-Dīn. Miftāh al-Jannah fī al-Ihtijāj bi alSunnah. Madinah: al-Jāmi'ah al-Islāmiyyah, 1399H.

Al-Ṭabarí, Muhāmmd bin Jarìr, Tahdhīb al-Āthār wa Tafșì al-Thābit 'an Rasūl Allāh min al-Akhbār. Kaherah: Matba'ah al-Madani, t.t.

Al-Tabrizīi, al-Mirzā 'Alì al-Ghurawì. Al-Tanqīh fī Sharh al-'Urwah al-Wuthqā Taqriran li Bahth Āyah Allāh al'Uzmōa al-Sayyid Abū al-Qāsim al-Mūsawi al-Khaw'ì. Qom: al-Hādi li al-Maṭbū'āt, 1410H.

Al-Ṭabāțabā'i, Muhammad Sa'id al-Hakìm. Al-Ușūliyyah wa al-Ikhbāriyyah: Bayn al-Asmā' wa al-Wāqi '. Najaf: Dār al-Hilāl, 2005.

Tarịhī, Fakhr al-Dīn. Majma' al-Bahrayn. Tehran: Murtadawi, $1416 \mathrm{H}$.

Al-Tỉjānì, Muhammad. Al-Shì'ah Hum Ahl al-Sunnah. Qom: Markaz al-Abhāth al-'Aqā'idiyyah, 1427H.

Al-Tỉjāni, Muhammad. Thumm Ihdaytu. London: Mu'assasah al-Fajar, 1991.

Al-Tirmìdhī, Muḥammad bin 'Isā. Al-Jāmi' al-Ṣahịh. Beirut: Dār Ihyā' al-Turāth al-'Arabì, t.t.

Al-Tūsi, Muḥammad bin al-Hasan. Tadhīb al-Ahkām. Tehran: Dār al-Kutub al-Islamiyyah, 1407H.

Al-Wirdāni, Șāliḥ. Ahl al-Sunnah Sha'b Allāh al-Mukhtār: Dirāsah fí Fasād 'Aqū'id Ahl al-Sunnah. Kaherah: Maktabah Mabdūli al-Ṣaghīr, 1996.

Wizārah al-Awqāf wa al-Shu'ūn al-Islāmiyyah-al-Kuwayt. Al-Mawsū'ah al-Fiqhiyyah al-Kuwaytiyyah. Kuwait: Dār al-Salāsil, 1404H. 
Mohd Aizam \& Mohd Fauzi, "Pemikiran Skeptikal Syiah terhadap Ahl alSunnah wa al-Jamā'ah," Afkār Vol. 21 Issue 1 (2019): 1-52

Al-Yāfi'‘i, Abū Muhammad. Mir'āh al-Jinān wa 'Ibrah alYaqzān. Kaherah: Dār al-Kitāb al-Islāmī, 1993.

Al-Zabìdi, Muhammad Murtaḍā al-Ḥusaynì. Ittihậf alSādah al-Muttaqīn bi Sharh Ihyā' 'Ulūm al-Dìn. Beirut: Mu'assasah al-Tārìkh al-'Arabī, 1994.

Al-Zabìdī, Muḥammad Murtaḍā al-Husaynī. Tāj al- 'Ārūs min Jawāhir al-Qāmūs. t.tp: Dār al-Hidāyah, t.t.

Zahìr, Iḥsān Ilāhì. Al-Shi 'ah wa al-Tashayyu'. Lahore: Dar Tarjuman al-Sunnah, 1984.

Al-Zirkilì, Khayr al-Dīn. Al-A 'lām. Beirut: Dār al-'Ilm li alMalāyīn, 1992.

\section{Laman sesawang}

“Al-abb al-rūhị li Aḥmadi Nijād: Man lam yaqbal bi hukm Wilāyah al-Faqīh yu'add murtadan", Al Arabiya, dicapai 14 November 2017 , https://www.alarabiya.net/articles/2010/06/14/111324.h tml.

"Debat Sunni Syiah Masjid Perling 2013: Analisis Ringkas", Meniti Titian Sebenar, dicapai 10 Januari 2016http://titian-sebenar.blogspot.my/2014/02/debatsunni-syiah-masjid-perling-2013.html.

"Debat Sunni vs Syiah Malayia, dicapai 10 Januari 2016, https://www.youtube.com/watch?v=NpSUIyUUwZE\&t $=42 \mathrm{~m} 38 \mathrm{~s}$.

"Khāmana'ì: Anā nā'ib al-Mahdi al-Muntazar wa țā'atí wajibah 'ala al-jami'", Al Arabiya, dicapai 14 November 2017 , https://www.alarabiya.net/articles/2010/07/22/114511.h tml.

"Senarai Perintah Larangan", Kementerian Dalam Negeri, http://epq.kdn.gov.my/epq/index.php?mod=public\&opt=pl. 15 Mei 2015.

"Ustādh fï Hawzah Qom, ghair al-mu'min bi Wilāyah alFaqih murtadd", Șuhf.net, 
Mohd Aizam \& Mohd Fauzi, "Pemikiran Skeptikal Syiah terhadap Ahl alSunnah wa al-Jamā'ah," Afkār Vol. 21 Issue 1 (2019): 1-52

https://www.suhf.net/world/315998/أستاذ_في-حوزة-قم-غير لفية 14 November 2017. 